\title{
DESCRIPTIONS OF NEW SPECIES AND GENERA OF LEPIDOPTERA, CHIEFLY FROM MEXICO.
}

\author{
By Harrison G. Dyar,
} Custodian of Lepidoptera, United States National Museum.

The following apparently undescribed species have mostly been received from Mr. Roberto Müller, of Mexico City, for identification. I have been assisted in placing some of the species by Sir George F. Hampson and Mr. William Schaus. Their assistance is specially acknowledged under each heading. All the species are from Mexico except in one family, the Cochlidiidæ, where species from Costa Rica and Brazil are described.

\section{Superfamily PAPILIONOIDEA.}

$$
\text { Family SATYRIDÆ. }
$$

\section{Genus EUPTYCHIA Hübner.}

\section{EUPTYCHIA PERTEPIDA, new species.}

Dark gray; a reddish shade over the middle of the fore wing, especially marked along the median vein and the bases of veins 3 and 4; a diffused band of erect scales across the disk beyond the median vein, cut by the reddish veins. Hind wing with the diffused reddish shade outwardly; two elongated blackish spots on the margin between veins 3 to 5 . Beneath the fore wings are reddish on the lower half; two brown lines cross the disk, and there is a row of submarginal lunate dusky spots. Hind wing brown-gray, the two median lines wavy and irregular, with a faint similar subbasal line, the outermost line followed by a bright reddish shade. A submarginal row of silvery scaling in a waved and broken line, crossing two velvety black oval spots on the margin, on which the silver forms irregularly geminate spots. Expanse, $35 \mathrm{~mm}$.

Female similar, but the whole discal area of fore wing overspread with bright brownish red, the lines of the underside slightly indicated, the sex mark absent. Hind wings red on the outer third. Underside as in the male. Expanse, $40 \mathrm{~mm}$.

Cotypes.- One male, two females, No. 13852, U.S.N.M., Mexico City, Mexico, November, 1910 (R. Müller). 


\section{Family NYMPHALID $\notin$.}

\section{Genus PHYCIODES Hübner.}

PHYCIODES CORACARA, new species.

Black above, the wings with white points; fore wing with four white spots beyond the cell, the upper pair on costa, the lower pair touching them, but more outwardly placed; two white points in the cell; two in submedian interspace; a larger one above vein 2; an outer row of seven small spots in an even curved line; a rather large lunule submarginally above vein 3 ; fringe checkered with white. Hind wing with the outer row of points and checkered fringe. Beneath the fore wing is as above, the spots somewhat enlarged, the ground color grayish. Hind wing with the disk pale yellow, the outer margin blackish shaded; a red mesial band composed of black-edged spots and one yellow one in the cell; a double subbasal black bar, stained with red; two rows of black dashes, nearly connected, running across the yellow disk, the inner one approximated to the mesial band, the outer free; a row of white points, inclosed by the blackish marginal shading; two submarginal white crescents; a terminal red line on both wings. Body pale yellow beneath, with lateral yellow spots; legs stained with reddish. Expanse, $30 \mathrm{~mm}$.

Cotypes.-Ten specimens, No. 14029, U.S.N.M., Sierra de Guerrero, Mexico, July, 1910 (R. Müller); Iguala, Guerrero, Mexico, 2,400 feet, June, 1906 (W. Schaus).

Mr. Schaus has kindly examined a specimen and informs me that the species is undescribed.

\section{Family RIODINIDÆ.}

\section{Genus CARIA Hübner.}

CARIA MELINO, new species.

Dark leaden gray with small black spots which have green metallic luster; fore wing with a spot in cell; a row of small ones beyond and a double marginal row; hind wing with distributed spots, hardly forming rows, the double marginal rows almost forming lines, with a coppery reddish tinge between and at base of fringe. Beneath dull red, the spots repeated and more distinct, being generally distributed over base of fore wing as well as hind wing; a broad dark shade over apex of fore wing and narrowly along margin of hind wing; inner margin of fore wing gray. Expanse, $22 \mathrm{~mm}$.

Cotypes.-Two males, No. 14282, U.S.N.M., Tehuacan, Mexico, September, 1910, June, 1911 (R. Müller). 
CARIA STILLATICIA, new species.

Ground color red-brown, overlaid with blackish on inner (lower) half of fore wing and basal three-fourths of hind wing; veins broadly lined with leaden black which has a leaden blue reflection in oblique light; spots small, black, in about five rows, the next to the last row being elongate and replaced below vein 3 by a bar of metallic blue. On the hind wing the spots are less distinctly in rows, but the blueleaden half-band is present and there is also a longer similar band close to the margin. Beneath of a bright brown-red, the black spots repeated and distinct, each with a patch of leaden-silvery scales, which form a nearly continuous line along the margin of both wings; fringe dark leaden gray; costa of fore wing gray with five small yellowish dashes; inner margin of hind wing gray. Expanse, $26 \mathrm{~mm}$.

Type.-One male, No. 14283, U.S.N.M., Sierra de Guerrero, Mexico, July, 1911 (R. Müller).

Family LYCÆNIDÆ.

Genus THECLA Fabricius.

THECLA PRIMNOZA, new species.

Wings black above, shaded with light blue on basal two-thirds of inner margin of fore wing below cell, over most of hind wing, except apex and a row of marginal spots; a blue line at base of fringe, which is white-tipped; long tail at end of vein 2 white-tipped. Costa of fore wing strongly angled near base in both sexes; male with a brand of dark gray scales extending subcostally, the brand nearly as long as half the length of the wing. Beneath dark gray; fore wing with a wavy white line beyond the middle, which is broken at vein 2 and lost in the whitish inner shading below; a submarginal row of whitish lunules, filled outwardly with whitish above and with blackish below. Hind wing gray on the basal third, washed with whitish beyond; a neat white crescent in the cell; three white lunules below and beyond, followed by a curved line of lunules across the wing at about the middle; another line at outer third, less distinctly lunular and edged without with dark; a black dot with red within above vein 2 ; some gray clouding before the termen; a terminal dark line; fringe whitish. Expanse, $30 \mathrm{~mm}$.

Cotypes.-One male, one female, No. 14277, U.S.N.M., Misantla, Mexico, June, 1911 (R. Müller); Santa Rosa, State of Vera Cruz, Mexico, May, 1906 (W. Schaus).

This is allied to T. primno Godman and Salvin, of which the male is unknown. The very peculiar-male sex mark will readily distinguish this group. 
THECLA ZENAIDA, new species.

Black, the male overspread with metallic blue except the margins of the wings; an elliptical brown sex mark occupying the outer half of the cell; female with pale blue at base of fore wing and overspreading most of hind wing except the costal area. Beneath dark brown-gray; fore wing with a fine white submarginal lunulated line, terminating at vein 2, preceded by a broad dark gray shade; hind wing with a dark gray shade at base and subterminally; an inner lunulated white line which forms a number of irregular marks at the end of the cell; an outer irregularly lunulated line across the wing; a submarginal wavy dark line in a whitish field, with a black dot preceded by red above vein 2 ; edge white, with a black line at base of fringe; long tail tipped with white. Expanse, 29-31 mm.

Cotypes.-One male, one female, No. 14278, U.S.N.M., Santa Rosa, State of Vera Cruz, Mexico, August, 1906 (W. Schaus).

THECLA GREPPA, new species.

Black above, the fore wings dark blue on basal three-fourths in and below cell, the hind wing blue except extreme margin and costal area; long tail at vein 2 and short one at vein 3 tipped with white; sex mark double, the upper portion generally appearing slaty gray, the lower blackish brown. Beneath light silvery gray, nearly white; on fore wing a slightly bent white line beyond the middle preceded by a gray and red shade, which is cut by the white veins; the line stops at vein 2 ; submarginal line slender, gray, cut by the veins; hind wing with a mesial row of light red spots of irregular sizes, the second from the costa small and placed somewhat inward, the two next the inner margin forming a line and placed somewhat outwardly; a submarginal gray line, broken into lunules, covering a red spot with black center above vein 2 ; another red spot at anal angle; slight gray spottings along the margin. Expanse, $29 \mathrm{~mm}$.

Cotypes.-Three males, No. 14279, U.S.N.M., Misantla, Mexico, June, 1911 (R. Müller); Santa Rosa, State of Vera Cruz, Mexico, May and August, 1906 (W. Schaus).

This species is allied to T. philinna Hewitson, but is much whiter below.

Family HESPERIID无.

\section{Genus HETEROPIA Mabille. ${ }^{1}$}

HETEROPIA CYLEDIS, new species.

Bronzy brown, the wings above washed with yellowish at base, on the fore wing to the middle, on the hind wing nearly throughout, 
excepting only on costa and narrowly on outer margin; fringes checkered black and white; on fore wing a row of four whitish subhyaline spots from middle of costa directed toward tornus, the costal spot divided by a vein, the one in the cell indented; a spot between veins 3 and 4 and a little one beyord; an oblique subapical row of three small ones. Beneath the spots are repeated; the wing is gray at the tip, with streaks of white in which are black irrorations; a yellow shade on inner margin. Hind wing dark gray; a broad submarginal white band, distinct only centrally, fading out toward costa and anal angle, irrorated with gray; in the basal field are angular black markings forming a subcostal bar crossed by a median bar, with a branch running along the lower part of the white submarginal band. Expanse, $53 \mathrm{~mm}$.

Type.-Male, No. 14220, U.S.N.M., Tehuacan, Mexico, April, 1911 (R. Müller).

Genus THRACIDES Hübner.

THRACIDES URIDON, new species.

Black above, the body and bases of both wings shot with bright metallic blue. Fore wing with a whitish patch in the center, pointed outwardly. Beneath dark brownish gray; costæ of both wings white at base; fore wing with an oblique white band, broadening below, the ground color darker before and beyond it; a curved subapical dark bar. Hind wings with discal and median curved dark bands. Expanse, $49 \mathrm{~mm}$.

Type.-Female, No. 14221, U.S.N.M., Guerrero, Mexico, March, 1911 (R. Müller).

\section{Genus THORYBES Scudder.}

THORYBES THEDEA, new species.

Brown; fore wing with a broad black bar near the middle, not reaching costa nor inner margin, indented without at veins 2 and 3 ; two white specks beyond it in the cell and one subcostally; four subapical hyaline-whitish spots in an oblique row; a small blackedged spot above vein 3 ; a double one above vein 2 ; a double black spot above vein 1, its upper portion small and moved outward. Hind wing with traces of an outer mesial row of dark spots. Beneath on the fore wing the spots are more faintly repeated; inner margin broadly yellowish; hind wing with an outer mesial narrow dark band, faintly followed by yellowish spottings. Expanse, $40 \mathrm{~mm}$.

Type.-One female, No. 14274, U.S.N.M., Tehaucan, Mexico, June, 1911 (R. Müller). 


\section{Genus STAPHYLUS Godman and Salvin.}

STAPHYLUS LITUS, new species.

Black; the wings with a faint bronzy reflection, without markings. Head and collar with some cupreous scales. Beneath black with slight greenish reflection; palpi below, pectus and a double ventral line on abdomen white; a few white scales in the fringe at apex of fore wing. Scales in the costal fold yellowish. Expanse, $25 \mathrm{~mm}$.

Type.-One male, No. 14275, U.S.N.M., Sierra de Guerrero, Mexico, June, 1911 (R. Müller).

\section{Genus BUTLERIA Kirby.}

\section{BUTLERIA AEA, new species.}

Black above; fore wing with a minute white speck in the cell, an elongate one below, two beyond subcostally and an outer curved row of four, none above vein 4; hind wing with a mesial row of small specks, one below vein 2 distinct. Beneath a little powdered with brassy; white spots larger and more distinct; on the fore wings as above; on the hind wings a spot in cell; a mesial row of four, the upper two elongate and slanting in opposite directions; an outer row of six, the one near anal angle moved inward. Expanse, $19 \mathrm{~mm}$.

Cotypes.-Two males, No. 14276, U.S.N.M., Sierra de Guerrero, Mexico, June, 1911 (R. Müller); Oaxaca, Mexico (W. Schaus).

\section{Family PAPILIONIDA.}

\section{Genus BARONIA Salvin.}

\section{BARONIA BREVICORNIS Salvin.}

Besides the form of the female resembling the male, and which is figured in the "Biologia Centrali-Americana" there are before me two very dissimilar dimorphic forms, which seem worthy of description.

\section{Dimorphic form EUSEMNA, new.}

Wings fulvous above, the veins lined with black; fore wing with the costa black, a broken bar across the cell to vein 3 and one at end of cell; apex and outer margin black; three yellow elliptical spots in the interspaces beyond the cell, one below the costa, three in a line below vein 8 , and four submarginal, below vein 7 . Hind wing with the veins beyond the cell black-lined; a spot between veins 6 and 7 ; outer margin broadly black with submarginal fulvous spots between the veins. Beneath the fore wing is fulvous on the inner area, the silvery white markings on both wings being as in the typical form.

Type--One female, No. 14280, U.S.N.M., Sierra de Guerrero, Mexico, June, 1911 (R. Müller). 


\section{Dimorphic form PHRONIMA, new.}

Wings black above; two subapical rows of yellow spots on fore wing, the inner of four spots in a line, the outer of four in a very irregular row, no spot above vein 5; hind wing with the submarginal row present above veins 2,3 , and 4 , the one below vein 2 double, and a little one farther in above vein 6 . Beneath black, all the silver marks toward the base absent; on fore wing a spot in the cell and three outer irregular rows; on hind wing two outer rows of small spots between the veins.

Type--One female, No. 14281, U.S.N.M., Sierra de Guerrero, Mexico, July, 1911 (R. Müller).

\section{Superfamily SPHINGOIDEA.}

\section{Family SPHINGIDÆ.}

\section{Genus HYLOICUS Hübner.}

\section{HYLOICUS ADUMBRATA, new species.}

Gray, edges of collar and patagiae black. Abdomen broadly black on the sides with five elliptical pale-yellow segmentary spots; a narrow dorsal black line; venter gray with a central black line. Head and palpi gray with some black about the orbits. Fore wing gray; a black patch near base on inner margin; a black line above median vein, doubled beyond the cell and four dashes in the interspaces, the upper one joining the apical dash; a submarginal line below vein 4, running obliquely inwardly, edged with whitish without. Hind wing black with gray bands sub-basally, mesially and on margin. Expanse, $85 \mathrm{~mm}$.

Type.-One male, No. 13853, U.S.N.M., Zacualpan, Mexico, September, 1910 (R. Müller).

\section{Genus AMPLYPTERUS Hübner.}

AMPLYPTERUS GLOBIFER, new species.

Pale olivaceous ochery; legs brown; vertex of head and a large patch covering patagia olive brown. Fore wing with a large olivebrown patch near base close to inner margin, pyriform, the prolongation directed towards base, the upper edge crossing median vein. Sub-basal and faint double median lines erossing wing; outer line parallel to margin, brown, shading into an irregular shading that covers the outer third of wing; it becomes bluish and dark on inner margin and contains there a bent black line; above this there is a lightening and another at costa, this last squarely cut outwardly by a brown shade. Hind wing dark rose-color except on inner margin, with a broad submarginal brown shade, constricted opposite the sub- 
basal indentations of the margin; two mesial shaded lines, most distinct near inner margin, the outer one close to the submarginal shade. Expanse, $115 \mathrm{~mm}$. $^{\circ}$

Type.-One male, No. 13854, U.S.N.M., Mineras de Zacualpan (near Mexico City), Mexico, August, 1910 (R. Müller).

\section{Superfamily SATURNOIDEA.}

\section{Family SATURNIIDE}

\section{Genus ROTHSCHILDIA Grote.}

\section{ROTHSCHILDIA LICHTENBA, new species.}

Mouse gray; collar and base of abdomen with a broad white band; sides of abdomen white with a row of red points; a sublateral row of red patches. Fore wing with the inner band angled, white, broad, edged with red within and black without, the latter broken on the angulation, while the white is produced faintly along veins 2 and 3; discal hyaline spot rounded, touching the outer band, edged with white and black; outer band white, strongly crenulate within and edged with black, edged with powdery red without; submarginal space powdered with lilacine on its basal half throughout, the following clay-colored space edged with brown and divided by the veins and intravenular scallops into geminate patches; of these the subapical one contains three black spots; a white line from the apex with two teeth above limits the subapical pale lilacine area. Marginal space white within, clay-colored without, cut by the veins. Hind wing similarly colored, the inner band slight and concave; submarginal clay-colored band nearly filled by dumb-bell-shaped spots, black at their ends, red in the centers, followed by a dark line and little white patches near margin, representing the submarginal white of the fore wing. Expanse, $90 \mathrm{~mm}$.

Type--One male, No. 13855, U.S.N.M., Salina Cruz, State of Oaxaca, Mexico, September, 1906 (W. Schaus).

This species was determined as new by Mr. Schaus.

\section{Genus AGAPEMA Neumoegen and Dyar.}

AGAPEMA COPAXOIDES, new species.

Gray brown, the collar brownish white. Wings darker at the base without distinct inner line; discal mark rosy red, ringed with black, with linear hyaline center; outer line zigzag, linear, blackish, but defined chiefly by the following pale marginal space, which shades again darker to the edge; an apical white dash on fore wing with a crimson and black spot inwardly. On the hind wing the marginal space is less pale and the black zigzag line therefore less distinct. Expanse, $78 \mathrm{~mm}$. 
Type.-One specimen, No. 13856, U.S.N.M., Iguala, State of Guerrero, Mexico, 2,400 feet, June, 1906 (W. Schaus).

This species was determined as new by Mr. Schaus.

\section{Genus AUTOMERIS Hübner.}

AUTOMERIS MELMON, new species.

Fore wings rather sharply pointed at apex in both sexes. Male yellow, the fore wing with two outer lines of brownish gray spots, both nearly straight; discal mark a ring of spots around a central one; traces of an inner line. Hind wing with the disk ocher yellow, the inner margin pink; round discal ocellus with powdery white and a central white pupil; outer line black, evenly curved; submarginal line and fringe red-brown. Body dark yellow, the abdomen with dorsal dark rosy shading. Expanse, $51 \mathrm{~mm}$.

Female dark rosy brown, the fore wing nearly uniform; inner and outer lines and discal mark indicated by lines of white scales; submarginal line a slightly lighter shade with a deepening of the ground color within. Hind wing with the margin rosy instead of yellow and the submarginal reddish shade broader; otherwise as in the male. Body dark rosy. Expanse, $56 \mathrm{~mm}$.

Cotypes.-Two males, one female, No. 13857, U.S.N.M., Mexico, without exact locality, July 26, 1906 (R. Müller, Nos. 148 and 527).

\section{AUTOMERIS DANDEMON, new species.}

Male yellow, female dark rose color, as in the preceding, but the wings are not so pointed at apex. The submarginal line on fore wings of male is absent, and only faintly indicated in female, the outer line being nearer the margin than in melmon. Hind wings with the pink shading on inner margin spreading largely over the disk in both sexes, also the markings similar to those of metmon. In the female the submarginal band is scarcely darker than the marginal area.

Cotypes.-Four males, one female, No. 13858, U.S.N.M., Cuernavaca, Mexico, July and August, 1906 (W. Schaus).

Mr. Schaus took a specimen of this species to London for comparison and returned it without comment.

AUTOMERIS COLENON, new species.

As in the preceding species, but the lines crenulate and wavy. In the male a zigzag inner line is evident, the discal ringlet of dots is filled in with a brownish shade and there is an irregular waved submarginal line. In the female the lines are indicated by lines of whitish scales, the outer line strongly crenulate; submarginal line indicated by the limitation of the slightly paler marginal area. Hind 
wings of the male with a broad dark rosy shade on inner margin, the other markings as in the preceding species. Female with the disk dark orange, the outer bands and inner shade not strongly contrasted.

Cotypes.-Four males, two females, No. 13859, U.S.N.M., Cuernavaca, Mexico, July, 1906 (W. Schaus).

Mr. Schaus says that the female is in the British Museum under the name Automeris cogena Felder, but that it does not agree with Felder's figure.

\section{AUTOMERIS THYREON, new species.}

Male brownish tan-color, the fore wing with the inner line distinct, blackish, of three ares in a line and two strongly dislocated ones; discal mark of arcs in an ellipse with central spot, grayish filled; outer line blackish, of short ares in a straight line; submarginal line of brownish red spots, distinctly discolorous, in an undulating row. Hind wing with the disk orange-tan, the inner margin broadly dull rose; discal ocellus rather small, black, with central powdering and white dash; outer line black, evenly curved; submarginal line red. Expanse, $47 \mathrm{~mm}$.

Female purple-brown, abdomen dorsally coherous. Fore wing with the basal space and discal lunule broadly brownish ocher, paler than the rest of the wing; outer line of ocher lunules with a dark bordering shade without; a submarginal dark shade. Hind wing ocher with purplish brown shade on inner margin; discal ocellus and outer line black; submarginal line purple brown; fringe red-brown. Expanse $53 \mathrm{~mm}$.

Cotypes.-Thirteen males, two females, No. 13860, U.S.N.M., Cuernavaca, Mexico, June and August, 1906 (W. Schaus).

Mr. Schaus compared the female in London and labeled it "Seems also distinct; nothing like it here."

\section{Genus COLORADIA Blake.}

COLORADIA EUPHROSYNE, new species.

Dark gray; body parts nearly black; fore femora with some crimson hairs; antennæ testaceous; fore wing shaded with blackish, except across and beyond cell; lines broad, diffused, of the same dark color; discal spot round, black. Hind wing dark crimson with mesial blackish shade and broad outer border; discal spot round, darker. Beneath both wings crimson with mesial and broad outer bands; discal spots large, rounded, blacker than the bands. Expanse, $62 \mathrm{~mm}$.

Type-—one male, No. 14077, U.S.N.M., Mexico City, Mexico, July, 1910 (R. Müller). 
Family CITHERONIIDÆ.

\section{Genus CITHERONIA Hübner.}

\section{CITHERONIA BELEDONON, new species.}

Head and thorax variegated with yellow and vermillion; abdomen vermillion above, with yellow basal segmental bands, yellow below with lateral and subventral vermillion spots. Fore wing gray, the veins lined in red; a submarginal wavy orange-red band, broken above; a yellow spot at base, an angular one in cell and small one below base of vein 2; an outer row of spots between the veins, the two costal ones elliptical, large, and confluent, the ones below veins 4 and 1 moderate, pyriform, the others small, none below vein 5 . Hind wing with the ground yellow, the veins lined with red and a red basal shading; a red outer band, nearly pure red in the male, shaded with gray in spots between the veins in the female; a marginal gray band, cut into spots by the red veins, this band broadest and most distinct in the female, but present in the male also. Expanse: Male, $98 \mathrm{~mm}$.; female, $118 \mathrm{~mm}$.

Cotypes.-No. 14215, U.S.N.M., Cuernavaca, Mexico; male, May, 1911 (R. Müller); female, July, 1906 (W. Schaus).

Allied to $C$. mexicana Grote and Robinson, but with the costosubapical spots larger and paler yellow, the hind wings of the male round and fuller and marked similarly to those of the female.

\section{Genus ADELOCEPHALA Boisduval.}

ADELOCEPHALA XANTHOCHROIA, new species.

Orange yellow; fore wing with large sparse purplish strigæ; inner line slender, purplish, curved a little in the cell; discal mark double, the upper spot small, purplish, the lower white, angular, edged with purplish; outer line narrow, straight, from costa before apex to near middle of inner margin; a purplish shade along the fringe of the margin. Hind wing with a crimson patch on inner part of wing from base toward tornus, the inner margin itself yellow like the rest of the wing. Beneath, fore wing with a large black discal patch, containing two white points; an outer line on both wings, distinct only toward the apex. Expanse, $69 \mathrm{~mm}$.

Type.-Male, No. 14028, U.S.N.M., Misantla, Mexico, May, 1910 (R. Müller).

$20441^{\circ}-$ Proc.N.M.vol.42-12-4 


\section{Superfamily BOMBYCOIDEA.}

Family SYNTOMIID优.

Genus HYALEUCEREA Butler.

HYALEUCEREA AGYLLOIDES, new species.

White, without markings. The wings are narrow, the fore wing pointed, the apex depressed. Pectinations of the antennæ and eyes black. Expanse, $27 \mathrm{~mm}$.

Type.-Female, No. 13919, U.S.N.M., Orizaba, Mexico, January, 1911 (R. Müller).

\section{Family LITHOSIIDA.}

\section{Genus NYCTOSIA Hampson.}

NYCTOSIA POICILONOTUS, new species.

Front of head gray, vertex orange; disk of thorax orange, tegulæ and patagia gray; sides of thorax below orange and rosy; abdomen blue-black, the basal segment above rosy, the tip orange. Fore wing leaden gray. Hind wing rosy red with narrow costal and outer margin of dark gray. Beneath as above. Expanse, $40 \mathrm{~mm}$.

Type--Male, No. 14213, U.S.N.M., Mexico City, Mexico, June, 1911 (R. Müller).

\section{Genus AGYLLA Walker.}

AGYLLA IDOLON, new species.

White, head and collar dull ocher; fore wings gray beneath; legs and abdomen beneath tinged with dull ocher. Expanse, 27-30 mm.

The male has the antennæ with bristles and cilia; no secondary sexual characters.

Cotypes.-Male and female, No. 14272, U.S.N.M., Mexico City, Mexico, June and July, 1911 (R. Müller).

\section{ARDONIPSA, new genus.}

Fore wing with vein 5 present; hind wing with vein 5 present; fore wing without an areole; veins $7-8$ and $9-10$ on separate stalks; hind wing with vein 5 from middle of cell.

Genotype.-Ardonipsa melas, new species.

ARDONIPSA MELAS, new species.

Fore wing dull black; hind wing and body blue-black. Beneath black, with a greenish-blue reflection, stronger than above. Expanse, $26 \mathrm{~mm}$.

Type.-Male, No. 13953, U.S.N.M., Cuernavaca, Mexico, July, 1906 (W. Schaus).

The specimen was kindly examined by Sir G. F. Hampson, who labeled it "New genus and species near Ardonio." 


\section{Family ARCTIIDÆ.}

\section{Genus HALISIDOTA Hübner.}

\section{HALISIDOTA NIMBIFACTA, new species.}

Pale straw-yellow, the hind wings yellowish white, semihyaline. Fore wings opaque, pale yellow, the markings pale brown, faint and nearly obliterate; these are in the form of chainlike bands, with a dark discoloration at the end of the cell and a small speck in the submarginal band between veins 5 and 6 . The markings are much as in Halisidota thyophora Schaus but very much fainter as well as being more regular and chainlike. Expanse: Male, $22 \mathrm{~mm}$; female, $30 \mathrm{~mm}$.

Cotypes.-Two males, seven females, No. 13844, U.S.N.M., Santa Rosa, State of Vera Cruz, Mexico, July, 1906 (W. Schaus); Guadalajara, Mexico (Schaus collection).

KALISIDOTA NIMBISCRIPTA, new species.

Pale straw-color. Antennæ of the male broadly pectinated. Fore wing pointed, marked with many fine pulverulent confused lines; these consist of the ordinary transverse catenulate markings but confused and confluent; the submarginal and marginal rows are most distinct, the former a line of cusps, the latter of small ringlets; a darker dot above vein 5; a slight yellow shading through the cell and outwardly from it. Expanse, $45 \mathrm{~mm}$.

Type--Male, No. 13920, U.S.N.M., Iguala, State of Guerrero, Mexico, 2,400 feet, July, 1906 (W. Schaus).

Mr. Schaus determined this species as new and says it is near Halisidota nebulosa Rothschild.

HALISIDOTA CARINATOR, new species.

Allied to cinctipes Grote and schausi Rothschild, but smaller and more darkly colored. The ground color of the fore wings is ocher yellow, not the pale whitish ochery of the two species mentioned, while the hind wings are of a strong ocher yellow color throughout, not semihyaline whitish with yellow wash on the inner area. The markings are as in schausi, a little darker and more distinctly limited by their dark borders. Expanse, 37 to $47 \mathrm{~mm}$.

Cotypes.- Seventeen males, eight females, No. 13681, U.S.N.M., Orizaba, Mexico, April 11, 1906 (R. Müller), March 13, 1908 (F. Knab); Cordoba, Mexico, March 13, 1908 (F. Knab); Jalapa, Mexico (Schaus collection); Coatepec, Mexico (Schaus collection).

The species runs into a dark form resembling atra Druce. Several of the males have a tint of black in the hind wings, one being dis- 
tinctly black-shaded except along the margins of the wing. Another, from Orizaba, has the hind wings entirely black, the abdomen also black above, but the fore wings scarcely tinged by the dark color. Another, from Cuernavaca, has the hind wings still blacker, the abdomen deep black above, the fore wings brown, as described for futiginosa Rothschild. A female from Merida, Venezuela, agrees closely in color with the description of bricenoi Rothschild, but the markings of these two forms are so incompletely described that I can not decide whether my specimens should be referred to these species or not. If it should prove to be so, the present species must be known as Halisidota fuliginosa Rothschild, with bricenoi Rothschild as a synonym and carinator Dyar as the name of the normal light-colored form.

\section{HALISIDOTA SCHAUSI Rothschild.}

The specimens before me from Mexico and Venezuela appear absoutely identical, so that I am inclined to consider the races pallida Rothschild and meridensis Rothschild as unnecessary and would place the names in the synonymy. The species schausi itself is not strongly separated from cinctipes Grote, yet perhaps sufficiently so. Cinctipes inhabits Cuba and southern Florida, while schausi flourishes upon the mainland from Mexico to Argentina. The following race appears not to have been characterized by Rothschild, and, though not a Mexican development, may properly be considered here.

HALISIDOTA SCHAUSI RUSCHEWEYHI, new subspecies.

Similar to H. schausi braziliensis Rothschild, but pale, the markings faintly traced, and not relieved from the ground color.

Cotypes.-One male, three females, No. 13682, U.S.N.M., Buenos Aires, Argentina (G. Ruscheweyh).

HALISIDOTA UNDERWOODI Rothschild.

It appears to me very doubtful whether this should rightly be considered as a distinct species and not a race of cinctipes Grote. However, as cinctipes is well isolated geographically, and as underwoodi has thrown off a form in Arizona, davisii $\mathrm{Hy}$. Edwards, which is probably best considered as a species, I am inclined to let the names stand as Rothschild has placed them. $H$. underwoodi in its normal Mexican form has the markings broad and fully developed. My specimens have a tendency to melanism in the direction of atra Druce, though I have no dark ones before me. Rothschild defines a race from Trinidad and Guiana as smaller and paler with a larger discoidal stigma. The following form may perhaps be separated. 
HALISIDOTA UNDERWOODI MODALIS, new subspecies.

Similar to underwoodi underwoodi, but paler, with the discoidal stigma smaller and often disconnected from the costal markings. The size is the same.

Cotypes.-Two males, three females, No. 13683, U.S.N.M., Aroa, Venezuela (Schaus collection).

The markings of the abdomen beneath are as in interlineata Walker, rather than as in underwoodi, but I place it as a race of the latter on account of the markings of the upper side, the black edges of the wing markings being small and not diffused.

\section{HALISIDOTA UNDERWOODI INSTABILIS, new subspecies.}

In this form the markings of the fore wings are curiously reduced, with a tendency toward the pattern of davisii Edwards. The submarginal band is nearly completely obliterated, only a costal and marginal spot being left, with sometimes one between veins 4 and 5 . The black borders of the remaining markings are distinct; the mesial band traverses the wing as a narrow riband, spreading out on the inner margin in a black line nearly to base, and also generally outward to the remains of the submarginal band. Abdomen beneath with a broken lateral black line, but without ventral spots.

Cotypes.-Three males, No. 13684, U.S.N.M., Cuernavaca, Mexico, June and August, 1906 (W. Schaus). The August specimen is much lighter in color than the others and has the costal markings reduced and broken.

This may perhaps be the form referred to by Rothschild ${ }^{1}$ as occasional Mexican examples of Halisidota interlineata interlineata Walker, but I can hardly think so, as the males of interlineata as known to me are small, with pointed wings and the black markings very heavy on the costal area.

\section{Genus HYPOCRISIAS Hampson.}

\section{HYPOCRISIAS LISOMA, new species.}

Ground color soiled white, shaded with rather dark brown. The body parts are of a grayish cast from the sprinkling of brown on the pale ground. Fore wing soiled whitish, the brown markings much shaded and illy defined. The terminal space is dark brown, rather narrow, and just within it is a wavy band of pale conjoined spots of the ground color. There is another pale line beyond the cell but much narrower and less well defined and a still more obscure broader one across the middle of the cell. Discal mark reniform, outlined in brown, but not conspicuous; the wing is generally irrorated and 
shaded with brown. Hind wing soiled whitish, with a submarginal shaded brownish band. Expanse, $35 \mathrm{~mm}$.

Type.-One male, No. 13845, U.S.N.M., Mexico City, Mexico, July, 1910 (R. Müller).

HYPOCRISIAS BERTHULA, new species.

Ground color of fore wing pale yellow, appearing in a large spot at basal third of costa two spots above each other at the end of the cell, a half row of small spots beyond and a complete subterminal row; besides these are a few small spots subbasally and running down from the large costal spot. The rest of the wing is shaded with dark brown, heavily so over the median space and terminally, more lightly at base and subterminally. Hind wing yellowish white, with a discal mark, a brown terminal border on apical half and a slight subterminal marking of a row of saggitate connected markings on the veins. Expanse, $38 \mathrm{~mm}$.

Type--One male, No. 13846, U.S.N.M., Tehuacan, Mexico, September, 1908 (R. Müller).

This species resembles Hypocrisias minima Neumoegen, but the markings of the fore wing are different, while the hind wings are not immaculate as in that form.

\section{Genus AMMALO Walker。}

AMMALO PARANOMON, new species.

Head and thorax dark brown; abdomen brown with black segmental rings, the basal hairs above long and red, obscuring the bands on the basal segments; legs brown, becoming black outwardly on tibiæ and tarsi, inside of fore femora and tips of hind tibiæ reddish. Fore wing roughly squamose, dark umber brown with blackish markings; these consist of a stripe along costa and inner margin, the latter interrupted by reddish hairs at base; joining these are a small subbasal band, an inner broad curved band, a broad outer band nearly touching the marginal band; a square discal patch fused to the costal stripe; a terminal row of minute umber dots at the ends of the veins. Hind wing pale red with a broad gray submarginal band, narrowly separated from the gray fringe by reddish. Expanse, $58 \mathrm{~mm}$.

Type.--One male, No. 14273, U.S.N.M., Zacualpan, Mexico, June, 1911 (R. Müller).

This species would appear to be more allied to the genus Elysius than to the one in which I have placed it, but vein 10 is clearly stalked on both wings. Vein 8 of the hind wings is small and weak, faintly attaining the costa as is often the case in Elysius, but not in Ammalo. 
EPICRISIAS, nevv genus.

Hind wing with vein 4 present; hind wing with veins 6 and 7 separate; fore wing with vein 11 from the cell; vein 10 from the cell; palpi porrect; hind wing with veins $3,4,5$ separate; hind tibiæ with two pairs of spurs; fore tibiæ unarmed; vein 3 from near angle of cell; fore wing broad; proboscis fully developed; palpi with the third joint long, spatulate, smoothly scaled.

Genotype.-Epicrisias eschara, new species.

EPICRISIAS ESCHARA, new species.

Reddish orange; body orange, vertex of head and tegulæ ocherous, the following parts black: palpi, front, sides of thorax, legs, except fore coxæ, a lateral stripe on the abdomen, the pair becoming conjoined posteriorly and covering the venter of the last segment and half of the penultimate one; antennæ black, shorty pectinated in the female. Fore wing rosy orange, shading to orange along the costa and outer margin, the vestiture transversely squamose basally. Hind wing rosy, semitranslucent centrally, orange tinted along costa and margin. Expanse, $54 \mathrm{~mm}$.

Type-One female, No. 13847, U.S.N.M., Zacualpan, Mexico, June, 1910 (R. Müller).

\section{Genus CALIDOTA Dyar.}

CALIDOTA MOMIS, new species.

Body and legs gray, vertex of head and collar dull ocher, the latter with two large black points; abdomen ocherous above, with a row of dorsal black spots, well separated. Fore wing gray with three black points, one in the cell, two beyond, above the bases of veins 4 and 5, respectively; hind wing semihyaline whitish, the veins dark, the margin broadly gray shaded. Expanse, $50 \mathrm{~mm}$.

Cotypes.-Male, No. 13848, U.S.N.M., Jalapa, Mexico (Schaus collection); female, Misantla, Mexico, June, 1910 (R. Müller).

Allied to C. gemma Schaus from Venezuela.

CALIDOTA ALBATICOSTA, new species.

Head gray, crimson behind; thorax dark gray dorsally with a white line along anterior edge of collar, tinged with crimson beneath; abdomen crimson above with a dorsal series of small dark points; venter whitish with a lateral row of dark spots, the last two segments dark beneath. Fore wing dark gray, the costa broady white almost to apex. Hind wing white, the veins dark. Expanse, $37 \mathrm{~mm}$.

Type.-One male, No. 13849, U.S.N.M., Tehuacan, Mexico, September, 1910 (R. Müller).

This species in its wing shape and coloration resembles species of the genus Euchrtias, and is unlike most of the Calidota. 


\section{Genus EUCHATIAS Lyman.}

EUCHETIAS PARAZONA, new species.

Dark, blackish gray; back of head with two orange points and an orange stripe running to the base of the wing; fore coxæ crimson; abdomen red above with segmental black bands, the anal tuft white, gray below. Fore wing blackish gray, the costa orange yellow nearly to apex; fringes of both wings whitish. Expanse, $48 \mathrm{~mm}$.

Type.-One female, No. 14214, U.S.N.M., Misantla, Mexico, July, 1911 (R. Müller).

\section{Genus HYPHANTRIA Harris.}

HYPHANTRIA PENTHETRIA, new species.

Head and collar white, the palpal hairs, a spot on front and two on collar dark gray. Thorax yellowish white, the patagia striped with gray inwardly: Legs white, ringed with black, the fore femora and tibiæ marked with orange. Abdomen orange above, white beneath, with a dorsal series of transverse black marks, a lateral and small sublateral row of spots. Fore wing blackish gray, the veins lined with white except the discal cross-vein; the subcostal white streak above the cell is very broad as also on the basal half of vein 1, and there is a broad streak on the submedian fold, not reaching base or margin; fringe white except in a patch at vein 3 . Hind wing blackish with a white ray on submedian fold, the fringe white except at the end of vein 3 . Expanse, $34 \mathrm{~mm}$.

Type.-One male, No. 13850, U.S.N.M., Tehuacan, Mexico, August, 1910 (R. Müller).

\section{Genus ECPANTHERIA Hübner.}

ECPANTHERIA EURIPIDES, new species.

Head blue-black in front, yellowish white on vortex; tegulæ broadly blue-black with narrow orange edges; thorax greenish black, the patagia with orange edges. Abdomen orange with two dorsal rows of small black spots, a lateral row, the venter banded with black, the last segment wholly black. Fore wing cream color, crossed by rows of large angular deep black spots; a minute one at base; first row of two and a line below vein 1 ; second row of three narrow spots; third row of five large spots, either square or triangular; a double lunate bar at end of cell; fourth row of seven narrow spots; fifth row of four spots above end of median vein; sixth row marginal of four small spots above, each divided by pale veins, a streak above vein 4 , a large spot between 3 and 4, two between veins 2 and 3, obliquely divided, a large one between 1 and 2, obliquely divided by a narrow line, and small one on inner margin; the larger cross-lines of the 
cream colored ground have centering orange streaks. Hind wing pointed at tornus, orange yellow, with gray spot at end of cell and four small ones in a square near apex. Legs entirely black. Expanse, $50 \mathrm{~mm}$.

Type.-One male, No. 13851, U.S.N.M., Mexico (Ritchie, through J. Doll).

Allied to E. cotyora Druce, the markings blacker, more angular and differently arranged, the hind wings yellow and more pointed at tornus.

\section{Family NOCTUID E.}

Subfamily AGROTIN AE.

Genus POROSAGROTIS Smith.

POROSAGROTIS CAMALPA, new species.

Fore wing purplish gray; basal space broadly lighter gray; inner line pale, straight, of three shallow arcs, bordered with blackish, most strongly so without; claviform a pale dash, indistinctly darker outlined; reniform large, round, a little pear-shaped, gray; reniform also pale but with darker center; cell dark, but hardly filled with a different color; outer line pale, slender, excurved over cell, with a slightly darker inner edge; subterminal line irregularly waved, preceded by a dark shade; fringe pale. Hind wing cinereous with pale fringe. Expanse, $31 \mathrm{~mm}$.

Type.-Female, No. 13921, U.S.N.M., Mexico City, Mexico, August, 1910 (R. Müller).

\section{Genus EPISILIA Hübner.}

EPISILIA CYMINOPRISTES, new species.

Thorax and fore wings brownish gray, uniform, shining; a small dark dash in place of orbicular and a small spot for reniform; outer line a row of small dark dots, evenly curved, inconspicuous; terminal dots more distinct than these and more separated. Hind wing whitish with gray terminal line; veins darkened especially above cell. Expanse, $53 \mathrm{~mm}$.

Type.-Female, No. 13922, U.S.N.M., Mexico City, Mexico, August, 1910 (R. Müller).

\section{Genus LYCOPHOTIA Hübner.}

\section{LYCOPHOTIA PAMPOLYCALA, new species.}

Violaceous gray; fore wing with a broad ochraceous subcosta1 stripe, reaching to the reniform, with three light costal spots above it, equally spaced; reniform large, semilunate, pale ocherous, with a curved central brown line; orbicular pale, black ringed; a black inner 
margin to the reniform; a black broken line in submedian fold at base, followed by the black claviform; lines pale, rather broad and illy defined, their dark edges indistinct, the inner slightly wavy, the outer excurved over cell; subterminal line pale, incurved at submedian and discal areas; terminal space larger, with terminal row of black dots. Hind wing white, subpellucid, with a dark terminal line. Expanse, $33 \mathrm{~mm}$.

The female before me is similar, but the black shadings more distinct. The cell is filled in with black between the stigmata and there is a little black beyond the reniform; the basal mark is broad and continuously black, the claviform is fuller, while the terminal space has the veins black-lined. Hind wing with gray shading at the apex. Expanse, $35 \mathrm{~mm}$.

Cotypes.-No. 14210, U.S.N.M., male, Cuernavaca, Mexico, May, 1911 (R. Müller); female, Guerrero, Mexico (J. Doll).

LYCOPHOTIA RICHIOIDES, new species.

Pale clayey ocherous; fore wing powdered with gray-brown, leaving the lines of the ground color; a black dot near the base; inner line straight, oblique, edged with blackish outwardly on outer half below; orbicular and reniform large pale rings with dark powdering between; outer line evenly curved over cell; submarginal line slightly waved. Hind wing with the veins soiled and dark discal spot. Expanse, $43 \mathrm{~mm}$.

Type.-Female, No. 14211, U.S.N.M., Cuernavaca, Mexico, May, 1911 (R. Müller).

LYCOPHOTIA TRIPHÆNOIDES, new species.

Fore wing reddish ocherous, the terminal space clayey ocher; reniform large, solidly black; outer line far out, curved, pale, with slight dusky edging; subterminal line a row of dots, slightly waved; a row of minute terminal dots. Hind wing blackish, the fringe pale, with dark discal mark. Below all pale, with dark discal marks and outer line on both wings. Expanse, $41 \mathrm{~mm}$.

Type.-Female, No. 14212, U.S.N.M., Mexico City, Mexico, May, 1911 (R. Müller).

Subfamily HADENINAE.

Genus POLIA Ochsenheimer.

POLIA TRASCA, new species.

Rather dark gray; basal space narrowly gray, with a pale subbasal line picked out by black spots; subbasal space broadly submetallic olivaceous; inner line black, oblique, nearly straight; mesial space space dark gray, the orbicular and reniform paler, faintly darkoutlined; outer line black, oblique, reversed in direction to the inner 
line, the pair approaching on inner margin, excurved over cell; subterminal line whitish, wavy, indistinct; a black dash above tornus, with whitish dash below it. Hind wing whitish, gray-shaded at apex and narrowly on outer margin. Expanse, $23 \mathrm{~mm}$.

Type.-Male, No. 13923, U.S.N.M., Tehuacan, Mexico, August, 1910 (R. Müller).

POLIA CLEPTOSCHEMA, new species.

Fore wing gray, rather irregularly mottled; a white dash at the base, divided and bordered below by black scales; inner line of three whitish segments, not well connected nor distinctly bordered; claviform outlined in black, broad; orbicular a minute black circle; reniform black-outlined, with a white line on the outer side of the center; outer line black, single, excurved over cell, dentate on the veins, strongly so on vein 1 with a white cusp in submedian interspace; subterminal line black, forming a dash on costa, a longitudinal dash above tornus with white speck below it; fringe pale with central wavy black line and two rows of dots. Hind wing whitish, stained with gray at apex and narrowly on outer margin. Expanse, $27 \mathrm{~mm}$.

Type--Male, No. 13924, U.S.N.M., Tehuacan, Mexico, August, 1910 (R. Müller).

\section{Genus HYSSIA Guenée.}

HYSSIA NEPHROSTICTA, new species.

Brown-gray; lines black, geminate, the filling somewhat paler than the ground; subbasal dentate; inner crenuiate; a black arc for claviform; orbicular a black ring; reniform filled in with white, somewhat broken and spotted; outer line excurved over cell; terminal space darkly shaded, through which runs the black subterminal line irregularly waved. Hind wing shaded with brownish gray, the fringe pale. Expanse, $20 \mathrm{~mm}$.

Type.-Female, No. 13925, U.S.N.M., Tehuacan, Mexico, September, 1910 (R. Müller).

This species was determined as new by Sir G. F. Hampson.

\section{Genus CHABUATA Walker.}

CHABUATA RECTINUBILA, new species.

Fore wing powdery brownish gray, the lines obliterate; a subterminal oblique straight pale shade from near apex to outer fourth of inner margin; a straight mesial dark shade; lines in part faintly traceable, the reniform the most distinct, large, dark-filled; a pale terminal line; fringe the color of wing. Hind wing gray, whitish over the disk. Expanse, $33 \mathrm{~mm}$.

Type.--Female, No. 11318, U.S.N.M., Orizaba, Mexico (Schaus collection). 
CHABUATA GRISEAGO, new species.

Fore wing light powdery gray, the markings obliterate; a diffused whitish shade from apex to outer fourth of inner margin, followed by a dark shade, the terminal part of the wing beyond this line darker than the rest; the whitish line is obscurely geminate; a slight discoloration at the end of the cell. Hind wing gray, a little lighter in the cell; fringe pale. Expanse, $28 \mathrm{~mm}$.

Type.-Male, No. 13926, U.S.N.M., Mexico City, Mexico, July, 1910 (R. Müller).

\section{Genus ERIOPYGA Guenée.}

ERIOPYGA CYMAX, new species,

Light red-brown; lines faint, gemirate, dark red, the filling slightly pale; reniform ocher with two black points, the upper concrete, the lower diffused; subterminal line pale, wavy, faint like the fillings of the other lines. Hind wing blackish gray, the fringe pale red. Expanse, $33 \mathrm{~mm}$.

Type.-Male, No. 13927, U.S.N.M., Misantla, Mexico, June, 1910 (R. Müller).

The species has broad, rather square wings.

ERIOPYGA MELANOPS, new species.

Dark gray; orbicular and reniform solidly black-filled; lines inconspicuous, the subbasal picked out in black; inner line double, with a black mark at claviform; outer line indistinctly doubled, the outer segment dentate, forming small streaks; terminal area darker, the subterminal line pale, narrow, scarcely waved, yet not rigid; a pale, line at base of fringe. Hind wing gray, lighter on basal two-thirds. Expanse, $28 \mathrm{~mm}$.

Type.-Male, No. 13928, U.S.N.M., Zacualpan, Mexico, August, 1909 (R. MüHer).

\section{Subfamily CUCULLIINA.}

\section{Genus PSEUDANARTA Grote.}

PSEUDANARTA HETEROCHROA, new species.

Lightest part of ground pale ochery, largely overwashed with olivaceous; basal space narrowly olivaceous; subbasal space shaded with brown; inner line whitish, oblique, incurved below vein 1 ; brown marks for orbicular and reniform; veins pale over discal area, forming distinct points on veins 3 and 4; outer line whitish, curved, faint, followed above by a triangular dark cloud on costa; a subterminal black shade, from apex to outer third of inner margin, relieving the dentations on veins 3-4; a terminal row of dashes; fringe brown. Hind wing with the basal half dark yellow, the outer half black; fringe white. Expanse, $26 \mathrm{~mm}$. 
Type-Male, No. 13929, U.S.N.M., without definite locality (R. Müller, No. 1379).

This species was identified by Sir G. F. Hampson.

\section{Subfamily ACRONYCTIN AE.}

\section{CENTROCHLORA, new genus.}

Fore wing with areole; fore tibia with claw on inner side only; front without prominence; proboscis fully developed; thorax roughly clothed with hair and scales; palpi short, porrect, not exceeding the front; fore tibia short, not twice as long as its claw.

Genotype.-Centrochlora esmeralda, new species.

Examined by. Sir G. F. Hampson, who labeled it "Gen. nov. near Agriopodes, in key near Centrartha." He also suggested the names here used.

\section{CENTROCHLORA ESMERALDA, new species.}

Dark green, collar with white points behind, patagia with white lines and two points on posterior side of disk. Fore wing green (faded to yellowish in the specimen); a white point at base; orbicular, reniform and claviform large white spots; a broad white subterminal band; black markings a triangular patch at base, nine dots on costa, inner line below median vein, excurved between the veins, outer-and inner edges of discal spots, twin bars between claviform and outer line, subterminal line broken, powdery, sharply pointed inward on submedian, and a row of spots in the fringe. Hind wing whitish, possibly originally stained with green outwardly. Expanse, $29 \mathrm{~mm}$.

Type-Male, No. 13930, U.S.N.M., Mexico City, Mexico, July, 1909 (R. Müller).

\section{Genus SIMYRA Ochsenheimer.}

SIMYRA UNIFACTA, new species.

Pale straw color; fore wing evenly and finely irrorated with brown, forming slight longitudinal streaks along the center of the wing and leaving the veins a little paler; no markings. Hind wing creamy white. Expanse, $38 \mathrm{~mm}$.

Type-Male, No. 13931, U.S.N.M., Misantla, Mexico, June, 1906 (R. Müller).

\section{Genus PERIGEA Guenée.}

PERIGEA MENOTA, new species.

Dark gray, mottled, strigose, the ordinary lines and spots not well relieved; reniform and orbicular large, concentric-ringed; edge of the reniform picked out in white; outer line smooth, gently excurved in the middle; subterminal line the edge of a dark shade, relieved by whitish beyond; termen again dark. Hind wing grayish, darker on the veins, a submarginal indistinct paler area. Beneath powdered with gray; termen of fore wing sharply pale; hind wing with a black 
discal point, a mesial narrow line, and a subterminal shaded broad one. Expanse, $28 \mathrm{~mm}$.

Type-Female, No. 14216, U.S.N.M., Tehuacan, Mexico, September, 1908.

The specimen was determined by Sir G. F. Hampson, as Perigea concisa Walker. It is extremely close to that species in markings, but the form is much slenderer than any concisa in my series, while the hind wings beneath differ considerably.

\section{PERIGEA MICRIPPIA, new species.}

Head and collar reddish brown; disk of thorax silvery gray; abdomen pale gray. Fore wing silvery gray marked with reddish brown; the brown color along the costa forms a patch at basal fourth, a long one near the middle extending down between the large concolorous stigmata, a small patch above reniform and three dots beyond; a brown patch in base of cell before orbicular; a small quadrate patch below orbicular; outer line double, indistinct; a brown dash from apex to outer line, the subterminal space below it solidly filled with brown, the terminal space less brown but likewise solidly filled, the colors separated by a wavy luteous subterminal line; a dark dot above tornus; a row of fine terminal black dashes; reniform and orbicular defined from the ground color by the brown shadings and a median longitudinal grayish shade and also a few black specks on their margins. Hind wing soiled whitish, stained with brown on the termen, especially broadly so at apex. Beneath the costal region of fore wing and apex of hind wing is irregularly blotched with dark red. Expanse, $25 \mathrm{~mm}$.

Type--Male, No. 14238, U.S.N.M., Misantla, Mexico, January, 1911 (R. Müller).

\section{Genus APATELA Hübner.}

APATELA RAPIDAN, new species.

Uniform cinereous; fore wing with the inner line black, double, dentate; a black basal longitudinal line on submedian fold to end of inner line, with some black shading below it; orbicular round, black outlined, paler than the ground color; a dark line on costa; reniform dark, concolorous, with a black curved line for its inner border; outer line single but with a whitish inner edge, starting on costa above reniform, curving broadly outward, retracted below vein 4 , finely crenulate-dentate on the veins; a black streak crossing this line in submedian fold to termen; a row of terminal black dots in the fringe, becoming short dashes below. Hind wing pale grayish with a small dark discal dot and shaded outer line, the termen darkly shaded. Expanse, $32 \mathrm{~mm}$.

Type.-Female, No. 14240, U.S.N.M., Misantla, Mexico, May, 1911 (R. Müller). 


\section{Genus OXYCNEMIS Grote.}

OXYCNEMIS MEXICANA, new species.

Cinereous, faintly lilacine tinted; subbasal line black, angled; inner line black, curved, the space between a little lighter than the ground color; an irregular dusky mesial line, from costa at outer line, bent along median vein, then angled and running obliquely outward to middle of inner margin; a small dark mark in cell; outer line blackish, irregularly waved and crenulate, followed by a dark triangular shade at apex and then a pale area; terminal space again cinereous. Hind wing dark gray. Expanse, $22 \mathrm{~mm}$.

Type.-Female, No. 13934, U.S.N.M., Cuernavaca, Mexico, July, 1909 (R. Müller).

Determined by Sir G. F. Hampson. The claw on fore tibia is minute.

Genus LAPHYGMA Guenée.

LAPHYGMA NIGRESCENS, new species.

Thorax black; fore wing grayish clay color, shaded with black; basal space to inner line filled with black irrorations; upper half of median space confused with dark shadings, the dark mesial shade running through it; claviform outlined; orbicular and reniform pale, without distinct outlines and with black centers, that of the reniform in its lower half; a square black subapical patch; subterminal line blackish, waved; ordinary lines lost. Hind wing pure white, with fine gray line before the fringe. Expanse, $26 \mathrm{~mm}$.

Type.-Male, No. 13935, U.S.N.M., Tehuacan, Mexico, August, 1910 (R. Müller).

Determined by Sir G. F. Hampson.

Genus MONODES Guenée.

MONODES NIVEOPIS, new species.

Dark ocher-brown; inner line geminate, crenulate, blackish, clouded; claviform outlined, clouded; orbicular a bright white speck; median shade-line dark, inflexed on subcosta and median; reniform black-filled, nearly divided into two round spots; outer line dark, single, strongly incurved on subcosta, followed below by a row of dots; terminal space blackish shaded, through which runs the pale wavy subterminal line. Hind wing brown-black with a darker discal mark. Expanse, $29 \mathrm{~mm}$.

Cotypes.-Two females, No. 13936, U.S.N.M., Misantla, Mexico, May and December, 1910 (R. Müller).

Determined by Sir G. F. Hampson. 
MONODES CASSIDA, new species.

Fore wing warm brown; basal space blackish shaded; inner line whitish, slender, nearly straight, followed by a narrow dark line; orbicular a black point; reniform a small black elliptical spot; mesial shade line dark, angled outward in cell to reniform and again outward on submedian fold; outer line curved, pale, preceded by a row of black dots, followed by a blackish shading that fills all of terminal space; subterminal line pale, faintly indicated; a row of pale specks at base of fringe. Hind wing shaded with gray, with some reddish at anal angle; a small dark discal dot; outer line pale, faint, showing only at inner margin; a row of pale specks in fringe. Expanse, $20 \mathrm{~mm}$.

Cotypes.-Three females, No. 13937, U.S.N.M., Coatepec, Mexico, October, 1910; Orizaba, Mexico, November, 1910; Misantla, Mexico, January, 1911 (R. Müller).

Sir G. F. Hampson kindly examined this with the others and labeled it "Monodes, not good enough to describe." The specimen, however, appears to me to be in good condition except that the apex of one wing is torn off. I have also received two others in good condition. The species is perhaps the same as Micromonodes mochensis Schaus.

\section{Genus AMIANA Dyar.}

AMIANA ENDOPOLIA, new species.

Light umber brown, washed with darker shades; inner line geminate, its outer segment black, the inner scarcely defined, the space between more or less completely filled by white powdering; the line is retracted a little in cell and distinctly so on submedian; lower part of median space filled solidly with white scaling or powdered with white, this area obliquely limited above, on the inner side reaching up to the cell; median shade-line shown as a zigzag of the dark ground through the white area; orbicular and reniform powdery white-filled, black-edged but not contrastingly so, irregularly black-centered; outer line black, single, strongly dentate on the veins, the dentations with minute capitate tips, the line cutting the extreme edge of the white patch on inner margin; subterminal line blackish, waved, with an elongate dark cloud opposite lower edge of reniform and one on margin above tornus; fringe shaded with black with a row of pale specks at base. Hind wing grayish brown, with discal mark and double outer dark bands, shaded and obscure. Expanse, $37 \mathrm{~mm}$. Cotypes.-Two females, No. 13938, U.S.N.M., Tehuacan, Mexico, September, 1908, September, 1910 (R. Müller).

The whitest specimen was examined by Sir G. F. Hampson and the name here used was suggested by him. 


\section{Genus ACHATODES Guenée.}

\section{ACHATODES METALEUCA, new species.}

Fore wing very light reddish brown, the markings obliterate; orbicular and reniform large, rounded, paler; a whitish space at apex, sharply obliquely limited inwardly, from which a brown submarginal line parallel to outer margin is faintly traceable. Thorax whitish. Hind wing white, thin and silky. Expanse, $32 \mathrm{~mm}$.

Type.-Male, No. 13891, U.S.N.M., Tehuacan, Mexico, June, 1910 (R. Müller).

Determined, and the name suggested by Sir G. F. Hampson.

Genus ERYTHRCEIA Hampson.

ERYTHRCECIA EUPOSIS, new species.

Thorax and fore wing yellow, much spotted with rose-pink. A row of spots along costa; two in base of cell; orbicular and reniform large, touching subcostal vein; two large spots below orbicular in a line to inner margin; a row of minute ones mesially; an outer band of spots of three rows close together and partly confluent; a neat terminal row of round spots between the veins; a row of confluent spots in the fringe. Hind wing black, the fringe white. Abdomen black, the tips of the segments pale, whitish beneath. Expanse, $36 \mathrm{~mm}$.

Type.-Male, No. 13892, U.S.N.M., Tehuacan, Mexico, September, 1910 (R. Müller).

\section{Genus PAPAIPEMA Smith.}

PAPAIPEMA APICATA, new species.

Dark brown, bases of antennæ and patagia with white spots; fore wing dark brown, nearly solidly so on lower half to tornus; base white, crossed by a fine brown line; a white speck in base of cell; claviform a large white elliptical spot with a white dot just above its upper edge and a fine line running across cell; seven white spots on costa; orbicular round, white, with a brown central dot; reniform with yellow center and fine brown line, two white spots before it and four on the outer border; a white elliptical spot at apex, cut by two brown veins and showing faint spottings submarginally below; a dark line at base of fringe. Hind wing cinereous shaded, the veins darker; fringe pale. Expanse, $30 \mathrm{~mm}$.

Type.-Female, No. 13893, U.S.N.M., Zacualpan, Mexico, September, 1909 (R. Müller).

Examined by Sir G. F. Hampson, and the name suggested by him. 20441ㅇ-Proc.N.M.vol.42-12-5 


\section{Genus OGDOCONTA Butler.}

OGDOCONTA PLUMBEA, new species.

Dark purplish brown; fore wing dark brown to beyond cell; following area lighter with a leaden purple shade, the margin again dark; lines faintly indicated by lighter scales, scarcely traceable except the subterminal which is twice waved. Hind wing dark gray, a little lighter at base, a black line on termen, followed by white in base of fringe. Expanse, $29 \mathrm{~mm}$.

Cotypes.-Male, No. 13894, U.S.N.M., Orizaba, Mexico, September, 1909 (R. Müller); female, Misantla, Mexico, July, 1910 (R. Müller).

This species was examined by Sir G. F. Hampson and determined as new.

\section{PERICONTA, new genus.}

Fore wing with an areole; tibiæ of fore legs short and stout, unarmed, the tarsi very short with large claws; front with conical process with vertical ridge; abdomen without crests.

Genotype.-Periconta obliqua, new species.

\section{PERICONTA OBLIQUA, new species.}

Dark purplish brown to the outer line; subbasal and inner lines slender, pale, faint; a black spot on inner margin between; orbicular and reniform faintly shown in pale; outer line an obliterate slender whitish line preceded by intensification of the dark shading; $a^{*}$ subterminal broad shaded very dark band, obsoletely cut by the veins; a pale line at base of fringe. Hind wing very dark gray with pale line at base of fringe. Expanse, $27 \mathrm{~mm}$.

Type.-Male, No. 13895, U.S.N.M., Tehuacan, Mexico, September, 1910 (R. Müller).

The genus and species were determined by Sir G. F. Hampson and the names kindly suggested by him.

\section{Genus SATRAPODES Hampson.}

SATRAPODES DOSCA, new species.

Thorax and fore wing bronzy yellowish; a brown bronzy shading from base along costa to below cell, narrowing at middle line, then filling the whole terminal area to a point at apex; three slender brown lines, the inner curved in an arc, the middle one bent at a sharp angle beyond cell, the outer at a still sharper angle, running from costa almost to outer margin, then straight to inner margin at its outer third; reniform a blackish cloud with a bright white spot below it; a white speck in cell; subterminal line nearly parallel to the outer margin, dark, wavy, rather broad, contained in the terminal dark shading. Hind wing dark brown, the fringe paler. Expanse, $30 \mathrm{~mm}$.

Type.-Female, No. 13896, U.S.N.M., Zacualpan, Mexico, September, 1910 (R. Müller). 
BISTICA, nevv genus.

Fore wing with an areole; fore legs unarmed; front with a truncate conical prominence with raised edges; and central point; eyes large; tongue distinct; abdomen with dorsal crest at base only; prothorax without crest; fore wing excavate on the outer margin below apex.

Genotype.-Bistica noela, new species.

BISTICA NOELA, new species.

Ocherous yellow; basal area of fore wing bronzy golden, limited outwardly by a brown line, which is incised on vein 1, nearly dividing the patch into two, one at base, one on inner margin; a similar golden area following the lower half of the outer line; a faint broad extramesial dark shade crossing the wing, its edges irregular; a dark speck in cell; reniform undifferentiated; outer line slender, strongly excurved over cell; submarginal line midway between it and the margin, less distinct and more flexuous; a narrow brown terminal line. Hind wing shining gray. Expanse, $22 \mathrm{~mm}$.

Type.-Female, No. 13897, U.S.N.M., Tehuacan, Mexico, September, 1910 (R. Müller).

This is probably Mychonia (?) noela Druce, figured in the Biologia Centrali-Americana, pl. 47, fig. 28, and I have accordingly used the same specific name.

\section{Genus ANTAPLAGA Grote.}

ANTAPLAGA STIGMATOSA, new species.

Thorax orange; fore wing golden yellow with black lines; inner line straight oblique, geminate, filled with powdery black; cell so filled; a black dash for claviform; orbicular large, round, white; reniform similar but less clear white and constricted; middle line single, dentate on the veins, separated from the dark cell only below median vein; outer line geminate, powdery-filled, dentate on the veins and also incurved opposite cell and on submedian; a terminal row of small black dots connected with larger spots in the fringe; hind wing brownish black, the fringe golden yellow with black spottings at base. Expanse, $27 \mathrm{~mm}$.

Type.-Female, No. 13898, U.S.N.M., Mexico City, Mexico, September, 1906 (R. Müller).

ANTAPLAGA HEMICROCEA, new species.

Thorax orange; fore wing golden yellow without markings; orbicular shown very faintly as a large paler area, and there are faint outlines of markings in dark orange, apparently as in the preceding. Hind wing and abdomen black, the wing with golden yellow fringe. Expanse, $25 \mathrm{~mm}$. 
Type.-Male, No. 13899, U.S.N.M., Zacualpan, Mexico, September, 1910 (R. Müller).

This may be a form of the preceding, with the markings obliterated. The undersides are alike in both, black with orange fringes and a yellowish spot in the cell of fore wing.

\section{ANTAPLAGA PLESIOGLAUCA, new species.}

Head, thorax and extreme base of fore wing golden yellow; rest of fore wing leaden brown with violet and blue reflections; basal third and three streaks in the outer field dark metallic purplish. Hind wing dull black, the fringes of both wings gray. Beneath gray, shading to yellowish toward base of costa and inner margin of fore wing and over basal half of hind wing. Expanse, $31 \mathrm{~mm}$.

Type.-Female, No. 13900, U.S.N.M., Sierra de Guerrero, Mexico, October, 1910 (R. Müller).

\section{ANTAPLAGA MELANOCRYPTA, new species.}

Vertex and thorax white; beneath, with legs and abdomen black; fore wing pure white; three little black dots at basal third, one on costa, one submedian, one on inner margin; two outwardly, one on inner margin, one on submedian. Hind wing black with white fringe. Beneath black; fringes of both wings narrowly white. Expanse, $27 \mathrm{~mm}$.

Type.-Female, No. 13901, U.S.N.M., Tehuacan, Mexico, June, 1910 (R. Müller).

Determined by Mr. Schaus as close to Antaplaga pyronæa Druce.

\section{Genus STIBADIUM Grote.}

STIBADIUM RAGLENA, new species.

Lustrous brown with a purplish tinge; inner line whitish, bent at right angles at median; reniform and orbicular large, whitish-ringed, filled with the shade of the darkest part of the ground color; outer line whitish, oblique, bent opposite the cell and reflexed to costa; terminal space lighter, the subterminal line whitish, twice waved, preceded by a dark shade which is indistinctly broken into rounded spots; a whitish shade at the pointed apex; fringe dark with a white line at its base. Abdomen and hind wing whitish with a little brown shading, spread uniformly over the wing and relieving a faint pale mesial line. Expanse, $37 \mathrm{~mm}$.

Type.-Female, No. 13932, U.S.N.M., Guerrero, Mexico (J. Doll collection).

Genus EMARGiNEA Guenée.

EMARGINEA NOCEA, new species.

Front and patagia white; collar black; fore wing creamy white, shaded with pale brown (probably originally olive green); basal space 
a pale creamy, lighter outwardly, terminating in an arc; upper half of median space velvety black except for a costal cream-colored space with curved lower edge that rests on the inner line and occupies twothirds of the costal distance of median space; outer line double, black, finely wavy; a row of black specks along the costal edge and in the fringe; terminal space mottled with pale brown (olive green?). Hind wing whitish, thin, a little shaded with gray, showing a faint discal dot and an outer wavy gray line, broken in the middle. Expanse, $25 \mathrm{~mm}$.

Type.-Female, No. 13933, U.S.N.M., Orizaba, Mexico, February, 1909 (R. Müller).

The specimen was kindly examined by Mr. W. Schaus, who labeled it "Emarginea, not in British Museum."

\section{Genus CHALCOPASTA Hampson.}

CHALCOPASTA RIANDANA, new species.

Thorax and fore wing ocherous irrorated with brown, the fore wing with large greenish bronzy patches; a triangular one at base, touching on median vein a spot that fills cell to end, crosses it to inner margin at middle of wing and fills in all the terminal area but the fringe, leaving a patch of the ground color on costa and covering the position of the reniform. Hind wing whitish, stained with gray in a submarginal band toward apex. Expanse, $33 \mathrm{~mm}$.

Type.-Male, No. 13902, U.S.N.M., Tehuacan, Mexico, September, 1908 (R. Müller).

CHALCOPASTA DYSNOA, new species.

Uniform bronzy brown; on fore wing the inner line is traceable as a darker line, bent at an angle on submedian; outer line similar, excurved over cell; a dark mark for reniform; outer margin a little excavate below apex. Hind wing dark brown, the fringe paler at tip. Expanse, $32 \mathrm{~mm}$.

Type.-Male, No. 13903, U.S.N.M., Tehuacan, Mexico, September, 1910 (R. Müller).

A female specimen from the same locality has a bright white spot in the cell and another larger one on the lower half of the reniform.

\section{Genus CIRRHOPHANUS Grote.}

CIRRHOPHANUS MIAIPHONA, new species.

Thorax and fore wing orange yellow, the veins and folds lined with dark brown except just at the margin where the linings fade out; inner line slender, red, straight, bent at right angles on median vein; a straight brownish red shade-band across middle of wing, touching the apex of the inner line; marking on the discal cross-vein a little heavier than the other linings; a faint oblique line beyond from costa 
to vein 7 ; no subterminal markings. Hind wing pale orange yellow, the veins a little darker. Expanse, $33 \mathrm{~mm}$.

Type.-Female, No. 13904, U.S.N.M., Guadalajara, Mexico (Schaus collection).

This species and Cirrhophanus papago Barnes, form a distinct section of the genus, perhaps worthy of separation.

\section{Genus STIRIA Grote.}

STIRIA ISCHUNE, new species.

Thorax gray-purple, vertex and collar stained with yellow. Fore wing golden yellow, marked with purple-gray; a small patch at base on inner margin; a large patch at the middle of the margin from which a waved outer line nearly attains costa; two discal dots and one in the cell; a gray patch on outer margin, widest in the middle, covering the fringe. Hind wing and abdomen dark gray, the fringe paler. Expanse, $37 \mathrm{~mm}$.

Type.-Male, No. 13905, U.S.N.M., Tehuacan, Mexico, September, 1910 (R. Müller).

Allied to Stiria rugifrons Grote, but with larger markings and dark hind wings.

STIRIA SISAYA, new species.

Vertex and collar yellow, thorax gray. Fore wing sulphur yellow; a small gray-brown patch on inner margin near base with a dot above it in cell; a small angular patch on middle of margin with a point inward on vein 1; four dots at end of cell; outer line fine, brown, wavy, and broken, incurved above vein 2; outer margin dark, with a widening above middle and near tornus. Hind wing pale gray, with whitish fringe. Expanse, $33 \mathrm{~mm}$.

Type.-Male, No. 13906, U.S.N.M., Tehuacan, Mexico, September, 1908 (R. Müller).

Allied to Stiria sulphurea Neumoegen.

STIRIA MOURIS, new species.

Vertex yellow, thorax dark gray, abdomen pale clay-color. Fore wing pale sulphur yellow; a gray patch at base on inner margin; a larger one at middle; outer line slender, wavy, running into this patch; orbicular a dark ringlet in cell; reniform of two dots and oblique costal shade; a large gray patch on outer margin, triangularly widening in the middle to touch the outer line; fringe dark. Hind wing white, a little soiled with gray along the outer margin. Beneath whitish, the apical half of fore wing overspread with gray. Expanse, $30 \mathrm{~mm}$.

Type--Male, No. 13907, U.S.N.M., Tehuacan, Mexico, September 1910 (R. Müller). 


\section{Genus STIRIODES Hampson.}

STIRIODES CONDISTICA, new species.

Thorax and fore wing sulphur yellow; three brown costal spots and one on center of inner margin; a dot in center of cell and one below vein 2; a faint line from the spot on inner margin followed by the two other similar lines and a row of faint dots, the latter submarginal; margin with a shallow subapical excavation. Hind wing straw yellow, brighter outwardly, the veins darker-marked; a mark on discal crossvein; a narrow mesial brown line and a broader submarginal one. Expanse, $30 \mathrm{~mm}$.

Type.-Female, No. 13908, U.S.N.M., Cuernavaca, Mexico, July, 1906 (W. Schaus).

\section{STIRIODES NEPOTICA, new species.}

A small species with the outer margin entire. Fore wing brownish ocher, shaded with dark brown except in a mesial band and on termen; two brown costal patches. Lines indistinct, showing faintly as rows of dots. Hind wing blackish with yellow fringe. Expanse, $16 \mathrm{~mm}$.

Type--Male, No. 13909, U.S.N.M., Salina Cruz, State of Oaxaca, Mexico, September, 1906 (W. Schaus).

\section{CIRRODISTIS, new genus.}

Fore wing with an areole; legs unarmed; frons with prominence with shovel-shaped process at middle; proboscis present; eyes large; thorax clothed with hair-like scales; plate below the frontal prominence short with pointed corners; fore wing with the outer margin doubly excavated; hind wing slightly excavated below apex.

Genotype.-Cirrodistis benedicta, new species.

CIRRODISTIS BENEDICTA, new species.

Thorax and base of fore wing bronzy brown, the color sharply limited by a darker line; rest of fore wing yellow; a faint mesial narrow line, broken across cell; outer line near the margin, narrow, brown, faintly duplicated; a brown line at base of fringe. Hind wing yellowish with a mesial line followed by dark shading half way to the margin with dentate edge; a brown line at base of fringe. Expanse, $30 \mathrm{~mm}$.

Type.-Female, No. 13910, U.S.N.M., Zacualpan, Mexico, September, 1910 (R. Müller).

LETABA, nev genus.

Fore wing with an areole; fore legs without spines; frons with a truncate conical prominence; thorax and abdomen without crests; eyes large, round; frontal prominence short, with flat tip, the edges 
scarcely raised; palpi oblique, thickened with scales, the end joint short.

Genotype.-Letaba noa, new species.

\section{LETABA NOA, new species.}

Black, the fringe of both wings white. Beneath, the tongue, basal joint of palpi, base of fore wing running along costa and basal half of costa of hind wing bright orange yellow; fringe as above. Expanse, $43 \mathrm{~mm}$.

Type.-Female, No. 13911, U.S.N.M., Zacualpan, Mexico, September, 1909 (R. Müller).

Mr. Schaus kindly compared this species in London and labeled it "Arctiid, quite new;" but it seems to me to be rather a noctuid, as vein 8 of the hind wings makes only a short anastomosis with the cell.

\section{Genus GERRA Walker.}

GERRA SOPHOCLES, new species.

Fore wing brown with a white oblique costal shade before apex; reniform and orbicular lighter brown; inner and outer lines very faint, dark; a light reddish submarginal row of joined spots bordered within with red-brown. Hind wing and abdomen dull gray-black, the fringe white. Beneath shining leaden black, the veins black; fringe of fore wing partly white; bases of both wings, tongue and base of palpi bright orange yellow. Expanse, $34 \mathrm{~mm}$.

Type.-Male, No. 13912, U.S.N.M., Cuernavaca, Mexico, July, 1906 (W. Schaus).

\section{Genus GERRODES Hampson.}

\section{GERRODES MINATEA, new species.}

Thorax and fore wing leaden gray, with brown streaks; an oblique whitish shading from before apex into cell, crossed by the brown streaks; a brown outer line parallel to outer margin above curves in below cell and joins the other streaks; closely following it a fine white line also curves inward and becomes a broad white band below cell, not reaching base; a slender whitish line beyond in the gray terminal space; a leaden line before the fringe. Abdomen yellow with a dark dorsal stripe. Hind wing orange-yellow with a rather narrow brown-black border; fringe whitish. Beneath both wings yellow with gray borders becoming black inwardly, the fore wing with an irregular discal mark. Expanse, $53 \mathrm{~mm}$.

Type.-Male, No. 13913, U.S.N.M., Zacualpan, Mexico, June, 1910 (R. Müller).

Allied to Gerrodes longipes Druce, but differing in the presence of the white bar and in the outer line, which is erect and not followed by a distinct second line. 
Subfamily ERASTRIIN AE.

\section{Genus MICTOCHROA Hampson.}

MICTOCHROA SELINITIS, new species.

Gray, the basal space clear and light gray; inner line curved, double, whitish showing on costa and inner margin; stigmata outlined in white, gray-filled, the reniform with a slender white center; a black dash through the cell and one on submedian, the former bisected by the reniform; outer line white, duplicated without, smooth, excurved over cell; terminal space dark but with white. powdering; subterminal line white, powdery, wavy; fringe dark, white-powdered, with a straight white line at base; a terminal row of black dashes. Hind wing brownish gray. Expanse, $20 \mathrm{~mm}$.

Type.-Female, No. 13943, U.S.N.M., Tehuacan, Mexico, June, 1910 (R. Müller).

Determined by Sir G. F. Hampson.

\section{Genus EUSTROTIA Hübner.}

EUSTROTIA ANITA, new species.

Basal space pearly gray; an erect black band across wing, narrow, constricted in cell and at vein 1, edged with whitish on both sides; outer portion of the wing washed with dull brownish red; costa spotted alternately ocherous and blackish; reniform an ocherous ringlet; subterminal line ocherous, strongly waved, preceded by a dark cloud on costa; a terminal black line; fringe gray. Hind wing heavily gray-shaded over a slightly ocherous ground. Expanse, $17 \mathrm{~mm}$.

Type.-Female, No. 13944, U.S.N.M., Orizaba, Mexico (Schaus collection).

\section{EUSTROTIA VICTRIX, new species.}

Thorax and base of fore wing smooth pale gray; a broad black band across wing incised within slightly in cell and on vein 1, narrowly pale-edged; outer part of wing ocherous, a little clouded with olive gray; reniform a large area without any olive clouding; subterminal line dark, twice incised, partly obsolete, the two points of the incisions the most distinct, except a triangular costal mark at its inception; fringe black, incised by the ocher ground at middle and slightly so subapically. Hind wing brownish-shaded, the veins darker, the fringe pale. Expanse, $18 \mathrm{~mm}$.

Type.-Male, No. 13945, U.S.N.M., Orizaba, Mexico (Schaus collection). 


\section{EUSTROTIA LIXINITES, new species.}

Base of fore wing clear gray; a dark gray patch on costa, dislocated from the band on inner margin, which is very wide on the margin, narrows abruptly into a rounded point above, terminating in the cell; space beyond ocherous, much overspread with gray outwardly; costa spotted ocherous and blackish; reniform an ocherous ringlet; subterminal line black, waved, broadest on costa; a light terminal line; fringe with a black patch at middle and at anal angle. Hind wing gray, fringe light, the veins and margin darker. Expanse, 24 $\mathrm{mm}$.

Type.-Male, No. 13946, U.S.N.M., Oaxaca, Mexico (Schaus collection).

\section{EUSTROTIA MELOR, new species.}

Base of fore wing gray; black band very broad, narrowing somewhat toward costa, indented in the middle a little on the outer side, edged with silvery on both sides; space beyond ocherous, strongly but irregularly shaded with blackish beyond the reniform; reniform an ocherous ellipse, scarcely defined; subterminal line pale, irregular, passing through the terminal clouding; fringe black, the color narrowly and somewhat irregularly staining the margin of the wing. Hind wing whitish in the male, with the veins dark, especially on the margin; solidly blackish gray in the female. Expanse, $18 \mathrm{~mm}$.

Cotypes.-Male and female, No. 13947, U.S.N.M., Cuernavaca, Mexico, July, 1906 (W. Schaus).

\section{EUSTROTIA MELORISTA, new species.}

Base of fore wing dark gray; black band broad, narrowing somewhat above, edged on both sides with silvery and within by orange also; space beyond orange; reniform faintly indicated, paler; subterminal line silvery, waved, preceded by a patch of black shading on costa and another just below it and a very small one on submedian; terminal space brown shaded; fringe dark gray with a black line at base, broken in the middle. Hind wing blackish brown, uniform. Expanse, $17 \mathrm{~mm}$.

Type.-Female, No. 13948, U.S.N.M., Iguala, State of Guerrero, Mexico, 2,400 feet, June, 1906 (W. Schaus).

\section{EUSTROTIA DISSOCIATA, new species.}

Base of fore wing pale gray, the outer two-thirds clayey ocherous; a black triangle on costa close to base, followed by a small dash; inner band broad and triangular on costa, constricted in cell, widened again below, and then constricted to a fine thread below vein 1 ; reniform a pale ellipse, filled and surrounded by an extensive grayish cloud; two dark dashes on costa; a triangular subapical patch; outer margin 
stained by two olivaceous grayish clouds; a broken terminal black line. Hind wing dark gray, the fringe pale, shining. Expanse, 20 $\mathrm{mm}$.

Type.-Female, No.14218, U.S.N.M., Tehuacan, Mexico, September, 1910 (R. Müller).

EUSTROTIA MEGAPLAGA, new species.

Gray, mottled and irrorate with olivaceous brown; a large black patch on inner margin, its inner edge erect, outer slightly oblique, upper edge nearly parallel to cell; indistinct gray streaks from costa and a wedge-shaped mark touching the upper angle of the patch; three gray dots at reniform; a broad dark shade across wing within the subterminal line, which is pale and faint, undulate; two curved dark patches on termen, the flexures between them at apex and middle. Hind wing shaded with gray-brown, powdery, the veins darker; fringe and terminal line dark. Expanse, $23 \mathrm{~mm}$.

Type.-Male, No. 13949, U.S.N.M., Tehuacan, Mexico, September, 1910 (R. Müller).

The specimen was examined by Sir G. F. Hampson and the name suggested by him.

\section{EUSTROTIA PLUMBIFUSA, new species.}

Gray, with a warm brownish tint on outer portion; basal space leaden gray, with an irregular black mark for the subbasal line; a broad leaden black band crosses the middle of the wing, angularly incised on its lower third with a point inward on vein 1 and a faint duplicating inner line; outer edge of the band roundedly but sharply incised on median vein; the band is plumbeous in the center and has black edges and a crossing bar on median vein; beyond this the ground is somewhat reddish, crossed by two slightly wavy brown lines, which become separated centrally; submarginal line brownblack, rather sharply dentate, especially mesially, followed by a whitish shade at apex; fringe leaden black, the color encroaching on the termen most widely at upper and lower thirds; a pale terminal line; a whitish speck at tornus. Hind wing gray-brown. Expanse, 22-24 $\mathrm{mm}$.

Cotypes.-Three females, No. 13950, U.S.N.M., Tehuacan, Mexico, June and August, 1910 (R. Müller).

One of the specimens was examined by Sir G. F. Hampson, who suggested the name here adopted.

\section{Genus ERASTRIA Ochsenheimer.}

ERASTRIA TILORA, new species.

Fore wing at base ocherous brown, shading into red-brown centrally; inner line dark, curved, indistinctly doubled, black on costa; reniform a black lunule, followed by leaden and three black dashes on costa; outer line whitish, narrow, broadened, ocherous-shaded and 
oblique on costa, forming two broad teeth opposite cell, then curved to inner margin, finely black-edged on both sides; terminal space soiled clay-color, obliquely brown from apex to median vein; subterminal line whitish, broadly waved and minutely crenulate, darkeredged, cutting off a small triangle from the apical dark shade. Hind wing grayish-shaded, the veins darker. Expanse, $19 \mathrm{~mm}$.

Type.-Male, No. 13951, U.S.N.M., Tehuacan, Mexico, September, 1910 (R. Müller).

\section{Genus TARACHE Hübner.}

TARACHE INTERPOSITA, new species.

Head and collar white; thorax leaden gray; fore wing broadly white along the costa, the inner area leaden gray with bronzy brown scales intermixed; a broad stripe of gray crosses the costal area at basal third, and there is an indication of another at apical third; the upper edge of the gray area is expanded at the positions of orbicular and reniform, although these spots are not otherwise defined and terminally the gray runs obliquely to apex. Hind wing whitish with a wash of gray, especially on the veins and apex. Expanse, $19 \mathrm{~mm}$.

Type.-Female, No. 13952, U.S.N.M., Tehuacan, Mexico, June, 1910 (R. Müller).

This species was determined by Sir G. F. Hampson, who labeled it "Near expolita Grote."

TARACHE VITTAMARGO, new species.

Head and collar silky white; front and thorax dark purple; abdomen whitish; fore wing dark purple, the costa broadly snowwhite to apical sixth; the lower edge of the white costal stripe is a little irregular and indented, its termination is parallel to the outer margin; the dark purple field is transversely marked with two darker, more reddish lines, corresponding to the usual inner and outer lines; anal angle broadly lilacine whitish, with detached gray-purple clouds along its inner edge and with two small black spots on the termen; fringe concolorous with the adjacent markings, being dark purple on upper third, then lilacine whitish, then purple on lower third. Hind wing white with straw-yellow tint. Expanse, $25 \mathrm{~mm}$.

Type.-Male, No. 14239, U.S.N.M., Tehuacan, Mexico, April, 1911 (R. Müller).

\section{Genus LITHACODIA Hübner.}

LITHACODIA MUSTAPHA, new species.

Fore wing gray, the claviform, orbicular and reniform outlined in black, but indistinct; a blackish costal wedge between the discal stigmata and a similar dark shade about the claviform; subterminal line broadly relieved by white on its lower two-thirds, itself blackish, 
denticulate, not strongly contrasted; the white occurs on both sides of the subterminal line, most continuously within and bordering the outer line, which is incurved below vein 2 . Hind wing pale cinereous. Expanse, $24 \mathrm{~mm}$.

Type.-Female, No. 14217, U.S.N.M., Mexico City, Mexico, July, 1910 (R. Müller).

$\mathrm{Mr}$. Schaus reports that this species is under Lithacodia musta Grote in the British Museum collection, and Sir G. F. Hampson determined a specimen.as L. musta. I think, however, that it is clearly distinct from that well-known species of the eastern United States, although allied to it.

\section{Subfamily CATOCALIN AE.}

\section{Genus CELIPTERA Guenée.}

CELIPTERA DIMERA, new species.

Fore wing light gray on basal half, finely irrorated with darker; costal edge black, the inner line arising from it as a black dash, then continued slenderly across the wing, incurved in the middle with a central outward tooth; a black line across the middle of the wing, formed of two arcs, touching on submedian, sharply edged within, diffused without, followed by a rosy brown color that covers the outer half of the wing; reniform absorbed in the median band; subterminal line pale, wavy, edged by darker cloudings; a terminal row of obscure blackish dots; fringe paler, approaching the shade of basal area. Hind wing faintly yellowish, reddish gray on terminal third, the veins a little-darker; a row of faint terminal dots; fringe whitish. Expanse, $30 \mathrm{~mm}$.

Type.-Female, No. 13955, U.S.N.M., Tehuacan, Mexico, June, 1910 (R. Müller).

This specimen was determined by Sir G. F. Hampson, who placed a question-mark beside the generic determination.

Subfamily NOC'NUIN AE.

\section{Genus DYOPS Guenée.}

DYOPS XANTHOLEPIS, new species.

Fore wing dark gray; basal space powdered with white with a central orange yellow dash; subbasal line black, broken, angled; inner line curved, white, dentate, with outer black edge, the white occluded except at the dentations, strongly black without the yellow basal mark; median line black, angularly dentate, suffused by a broad blackish shade that fills most of the median space; claviform a whitish shade; orbicular similar, small, a little defined on its edges by dark scales; reniform large, diffused, white, broken into three superposed spots, the middle one of which is orange yellow, and an inner spot, this latter separated by a slender line on the cross-vein; outer line black with narrow white shading without, dentate, strongly 
produced opposite cell in a square, the outer edge of which is irregularly dentate; terminal space powdered with white, especially next the outer line, a little yellow shaded below; submarginal line whitish, dentate, broken and more or less dislocated; fringe concolorous with the terminal space with white basal dots. Hind wing brown-black with some irregular white scales near anal angle. Expanse, $36 \mathrm{~mm}$.

Cotypes.-Two males, two females, No. 13956, U.S.N.M., Misantla, Mexico, May, 1909, May, 1910 (R. Müller).

Determined by Sir G. F. Hampson, who placed a mark of doubt by the generic name.

\section{Genus CASANDRIA Walker.}

CASANDRIA OLIVARIS, new species.

Costal area sordid ocherous, apparently originally olive green; inner two-thirds of wing gray; subbasal line gray, with an outward closed loop in the middle containing a few whitish scales; inner line gray with strong dentations in cell and on submedian; reniform an angular-pyriform line with central dot; outer line dislocated from a deep black mark on costa, strongly dentate, incurved below cell and remaining thence near middle of wing with a square outward production in submedian area; subterminal line whitish, clouded and obscure, but forming a white dot above tornus. Hind wing pale, washed with gray outwardly, the veins dark; fringe pale. Expanse, $31 \mathrm{~mm}$.

Type.-Female, No. 13957, U.S.N.M., Misantla, Mexico, August, 1910 (R. Müller).

Determined by Sir G. F. Hampson and the name suggested by him.

Genus PETEROMA Schaus.

PETEROMA ALTERNATA, new species.

Basal and outer two-thirds of median spaces black, the alternating areas brownish gray; basal area somewhat obliquely limited outwardly, with indentation in cell and on vein 1 , the black a shading upon a browner ground and indistinctly lined; the outer dark area just covers a dentate mesial line and is limited without by the outer line, black, dentate, incurved below vein 3 and followed by brown, a wavy terminal pale line with black dots at the incisions; fringe wavy. Hind wing brown; an outer curved black line running from tornus and lost above middle of wing; the line is clouded with brown and followed by a faint reduplication; a terminal crenulate black and pale line. Expanse, $41 \mathrm{~mm}$.

Type.-Male, No. 13958, U.S.N.M., Mexico City, Mexico, August, 1910 (R. Müller).

Mr. Schaus kindly examined this species and labeled it "Peteroma; nothing exactly like it in British Museum." 


\section{Genus CELIPTERA Guenée.}

\section{CELIPTERA CODO, new species.}

Brown, irrorated with blackish; subbasal line velvety black, obsolete below; inner line broadly curved, coarsely dentate, pale with a reddish tint, narrow, but distinctly edged with black on its oblique upper third; orbicular round, black; reniform black, clouded outwardly and throwing a spur from inferior angle back along median vein to below orbicular; outer line broad, even, gently curved, reddish brown without, shading to yellowish within, edged with a blackish line within and outwardly by a narrow yellowish line that is strongly crenulate, its cusps nearly cutting through the following clouded black band; terminal space of the ground color, not so strongly irrorate; a crenulate black line at base of fringe. Hind wing much the color of fore wing, lightening at base; a blackish shaded discal lunule; traces of a pale outer mesial line with dark edges; fringe as on fore wing. Expanse, $40 \mathrm{~mm}$.

Type.-Male, No. 13959, U.S.N.M., Tehuacan, Mexico, September, 1910 (R. Müller).

Mr. Schaus examined this specimen.

\section{Genus RHASENA Walker.}

RHESENA DEFECTA, new species.

Dark brown, somewhat bronzy, with a general mottled effect from the light and dark shades and numerous lines; outer line almost at the middle of the wing, crenulate, geminate, black, pale-filled, angularly bent at cell; beyond it about vein 6 a longitudinal yellowish silvery line touches submarginal line; subbasal and inner lines black, crenulate; subterminal line pale, with a dark shade within; this shade on lower two-thirds of wing, with another similar one within the outer line, are straight, black and conspicuous; ground between the lines mottled with black; discal spots black-ringed, but lost in the general mottling; a pale terminal line; fringe black spotted; outer margin excavate below apex. Hind wing black, with a brownish tinge, uniform. Expanse, $24 \mathrm{~mm}$.

Type.-Female, No. 13960, U.S.N.M., Misantla, Mexico, July, 1910 (R. Müller).

Sir G. F. Hampson kindly examined the specimen, but placed a mark of doubt by the generic reference, as the palpi are missing.

\section{Genus GONODONTA Hübner.}

GONODONTA PLUMBICINCTA, new species.

Thorax and fore wing rather dark ocherous brown; scarcely any markings to the outer line; a darker brown shade along costa, widening basally and toward apex, and two parallel oblique brown streaks 
below median vein at base; the outer line is broad, beginning with a dark brown line within, which forms a tooth inward below cell and is then continued very faintly to margin; following this is another line, similar, parallel, but not entering the tooth, separated by a purplish space; next a dark leaden band, then a light one, these interrupted above tornus and replaced by a narrow ocherous lunule; a wavy line following, then a dark shade, then a narrow terminal space of the ground color; fringe dark with blackish spots. Hind wing black with a small central lightening, which is digitately expanded, and is the remains of the central yellow patch usual in the genus. Expanse, $37 \mathrm{~mm}$.

Type--Male, No. 13961, U.S.N.M., Orizaba, Mexico, September, 1910 (R. Müller).

This was determined as new by Mr. Schaus.

\section{Genus CONCANA Walker.}

\section{CONCANA LEUCOMERA, new species.}

Fore wing purplish brown with a bronzy reflection; inner line black, curved, squarely angled on subcosta, then nearly even; reniform and orbicular outlined in black but indistinctly so, the reniform with a faint concentric lightening that forms a faint outward ray to outer line; outer line black, starting on costa above reniform, then strongly outwardly bent, forming a square projection with slight waves, returning across the discal venules to within reniform, bent at a sharp angle and continued down to inner margin with a flexure in submedian space; at the indentation it joins the median line which is similarly outflexed, crossing the reniform, but only its segment below the junction is distinct; subterminal line pale, wavy, maculate, forming a round yellowish spot above vein 2 and crossed by a black dash near vein 6 . Hind wing black, with a broad oval white space at base. Expanse, 30-35 mm.

Cotypes.-Males and females, No. 13962, U.S.N.M., Misantla, Mexico, May and August, 1910 (R. Müller); Orizaba, Mexico (Schaus collection).

Examined by Sir G. F. Hampson, who placed a question mark beside the generic determination.

\section{Genus ANTARCH EA Hübner.}

\section{ANTARCHAEA OBLIQUALIS, new species.}

Thorax and fore wing yellow; palpi crimson; outer half of wing shaded with crimson, leaving a line of the ground color which starts from apex obliquely and is bent at the level of the median vein, running toward base till it is lost in the ground color; the crimson edges this line above distinctly and it also runs inward on the inner margin; all its inner border is diffused; costa narrowly crimson. 
Hind wing white, a little washed with gray outwardly. Fore wing blackish shaded below with crimson fringe. Hind wing white. Expanse, $25 \mathrm{~mm}$.

Cotypes.-Females, No. 13963, U.S.N.M., Tehuacan, Mexico, September, 1908 (R. Müller); Mexico City, Mexico, July, 1910 (R. Müller).

Sir G. F. Hampson suggested the specific name, and remarks that the species is near to Antarchæa flacillalis Walker, an undescribed species in the British Museum from Arizona

ANTARCHAEA OMA, new species.

Palpi and orbits rosy; head, thorax, and abdomen whitish yellow. Fore wing whitish yellow with a gray overcast, the costa on basal fourth deep rose color; an oblique stripe from apex of a grayish color, bent parallel to costa near its middle and becoming obsolete before reaching base of wing; the stripe is edged below by clear yellow of the ground color, without the grayish shadings; fringe darkly gray-shaded. Hind wing pale straw color. Expanse, $36 \mathrm{~mm}$.

Type.-Female, No. 14237, U.S.N.M., Tehuacan, Mexico, May, 1911 (R. Müller).

\section{Family NOTODONTIDA.}

\section{Genus CERURA Schrank.}

CERURA DUONUMENIA, new species.

Fore wing gray, the normal white ground.appearing only at base below median vein and in two large lunate marks in the submarginal line abova veins 2 and 3 . Several irregular black lines across the wing, barely discernible, and a discal mark; submarginal line more distinct, velvety black in places, especially apically, and in streaks beyond cell and above vein 1 . The upper streak is dislocated inward and edged with white; the lower is somewhat lunate and also edged with white. A row of black dots in the fringe. Hind wing grayish, darkly on the veins and margin, the fringe whitish with dark spottings. A discal dot and mesial line showing through from beneath. Expanse, $32 \mathrm{~mm}$.

Type--One male, No. 13861, U.S.N.M., Tehuacan, Mexico, September, 1910 (R. Müller).

\section{Genus SCHIZURA Doubleday.}

SCHIZURA DOSPEPPA, new species.

Fore wing reddish gray; base shaded with blackish, especially subcostally; no markings beyond, except the lower half of the outer line, which is pale, waved and slightly bordered with blackish; sub- 
terminal line distinct, whitish, waved, edged with blackish, forming a white speck above vein 2, crossed by black streaks on veins 2 to 4 and followed by shorter streaks above. Hind wing white, a little yellowish shaded; a black spot above tornus cut by a pale line. Expanse, $33 \mathrm{~mm}$.

Type-Male, No. 14076, U.S.N.M., Iguala, State of Guerrero, Mexico, 2,400 feet, June, 1906 (W. Schaus).

\section{Family EUPTEROTID瓜.}

\section{Genus APATELODES Packard.}

\section{APATELODES HIANTHA, new species.}

Gray, the body dark gray, the patagia outlined in darker; fore wing with the inner line waved, geminate, obsolete except on inner margin, where it shows as two whitish cusps preceded by black; an oblique black line in brown shading from basal third of costa, directed toward tornus, which it does not reach; discal dot a whitish lunule; mesial line brown-black, angled outward over the discal mark, crossing the oblique streak below, not wavy; outer line crenulate, excurved a little above; a submarginal apical white line, its lower edge broken off as a round dot, preceded by black, longitudinally streaked; fringe concolorous with ground, which is darker terminally. Hind wing reddish gray with a curved whitish mesial line and dark scaling on the inner margin. Expanse, $34 \mathrm{~mm}$.

Type.-Male, No. 13914, U.S.N.M., Zacualpan, Mexico, August, 1909 (R. Müller).

\section{APATELODES DORAMIA, new species.}

Gray, a brown-black band on posterior edge of thorax; abdomen densely irrorated with brown: Fore wing gray, shaded with brown in lower part of madian space; a brown spot on inner margin, cut by an outwardly oblique white line; an oblique white line from basal third of costa, directed toward tornus, edged with brown; discal mark a whitish ellipse; mesial line indicated by a dark dash on costa; outer line whitish, not wavy, excurved in its upper third; a broken costo-subapical white line, preceded by two heavy black dashes. Hind wing reddish gray, with curved mesial white line, intensified on inner margin and bordered there by brown scaling. Expanse, $38 \mathrm{~mm}$.

Type.-Male, No. 13915, U.S.N.M., Cuernavaca, Mexico, July, 1906 (W. Schaus).

\section{APATELODES LESCAMIA, new species.}

Gray; base of thorax with a black band; abdomen with a dorsal row of spots. Fore wing dark gray, the basal area lighter, limited outwardly by a line formed of the oblique streak on inner margin 
and the oblique costal streak, which join; inner marginal one narrow, white, preceded and followed by black; costal one white, shaded, followed by black, the two meeting in a point; discal dot elliptical, pale; outer line whitish, not waved, sharply excurved above, darkedged within; a broken whitish costo-subapical line with shaded black streaks within. Hind wing reddish gray, with a faint pale line before the middle, becoming white on inner margin and there edged by dark scales. Expanse, $32 \mathrm{~mm}$.

Type.-Male, No. 13916, U.S.N.M., Tehuacan, Mexico, August, 1910 (R. Müller).

\section{APATELODES BATIMA, new species.}

Cinereous gray, the fore wing mottled with olivaceous brown; spot on inner margin brown, divided by a pale line; inner line brown, curved, throwing out at median vein an oblique streak, directed toward tornus; mesial line brown, shaded near the inner line; discal mark a faint pale cloud; outer mesial line brown, shaded, sharply excurved opposite cell and again slightly at submedian; outer line narrow, blackish, excurved opposite cell; a brown cloud on outer margin starting below the costo-apical white dots, which are preceded by brown. Hind wing washed with dull red, with mesial white line, preceded by a faint red one, all intensified on inner margin. Expanse, $44 \mathrm{~mm}$.

Type.-Female, No. 13917, U.S.N.M., Iguala, State of Guerrero, Mexico, 2,400 feet, June, 1906 (W. Schaus).

This species was determined as new by Mr. Schaus and sent to me for description.

\section{APATELODES BUNCA, new species.}

Brownish tan-color; tarsi marked with brown. Fore wing with the inner line black-brown, crenulate, interrupted in the middle, preceded by a geminate brown spot on inner margin; inner mesial line brown, wavy, faint; outer mesial line brown, clouded on inner margin by a large irregular patch; outer line narrow, black-brown, crenulate, excurved opposite cell, followed by patches of brown shading below; a white speck submarginally opposite the indentation on the outer edge of the wing; terminal shading and fringe brown. Hind wing shaded with reddish, the inner margin marked with a white cusp and brown dashes. Expanse, $46 \mathrm{~mm}$.

Type--Male, No. 13918, U.S.N.M., Cuernavaca, Mexico, June, 1906 (W. Schaus).

APATELODES MILMA, new species.

Grayish carneous; a velvety brown spot on collar and middle of thorax, expanding on posterior edge; fore wing with a mark on basal third of inner margin composed of two superposed spots within, 
followed by a short erect line; inner line brown, outwardly bent on median, then to inner margin, slightly flexuous; a brown cloud on outer half of inner margin, rising nearly to the cell and joining the faint mesial shade-band; outer line brown, dentate-lunulate, excurved below costa and parallel to outer margin; fringe brown; subapical mark a small white dot well below costa. Hind wing reddish except at base, with faint pale mesial line, which bears a brown spot on inner margin. Expanse, $45 \mathrm{~mm}$.

Type--Male, No. 14030, U.S.N.M., Jalapa, Mexico (Schaus collection).

Mr. Schaus writes that this species is under A. heptaloba Druce in the British Museum collection, but that it is really distinct from that species.

\section{Family GEOMETRID无.}

\section{Genus EPIRRHOE Hübner.}

EPIRRHOE CALISCATA, new species.

Fore wing gray, rather thinly scaled, with a broad black mesial band. Other markings less distinct. Basal space dark, limited outwardly by a double blackish line; median band limited inwardly by a blackish line, coarsely angulated on the veins and interspaces, with a whiter area preceding above vein 1; beyond this band and below vein 2, a red-brown line; outer line dark, shaded, waved, obsolete centrally, joining at tornus a broad dark marginal shade, also incised centrally. Hind wing white, nearly pure, with three black dashes on inner margin and a subterminal gray shaded line. Expanse, $30 \mathrm{~mm}$.

Type.-Male, No. 14222, U.S.N.M., Zacualpan, Mexico, September, 1909 (R. Müller).

\section{Genus EMMILTIS Hübner.}

EMMILTIS ORDINARIA, new species.

Creamy white, slightly gray-tinted on costa and veins; lines fine, wavy pale gray; five lines, inner and mesial well spaced, outer three close together near the margin, the inner of these three a little blacker and more dentately waved; a minute discal dot; fringe dark. Hind wing similar, the inner line faint, the mesial within the discal dot, the outer three less closely spaced than on fore wing. Expanse, $19 \mathrm{~mm}$.

Type.-Female, No. 14223, U.S.N.M., Orizaba, Mexico, September, 1909 (R. Müller). 


\section{Genus PROGONODES Warren.}

PROGONODES DIVERSATA, new species.

Green; head and collar white; abdomen white with dorsal dark shading and tufts. Fore wing with the costa white, powdered with green; a broad white subbasal band; a slender mark on the bent discal vein; an outer white band, excurved over the discal venules, its inner edge dentate, its outer edge diffused above and duplicated by small dentations, narrow at veins 3 and 4 , broadly diffused to tornus below and containing an upright blackish macular shade; a wavy white terminal line; fringe outwardly pale. Hind wing similarly marked, the outer line less dentate inwardly and running up along inner margin to base, the black marking at tornus small. Expanse, $30 \mathrm{~mm}$.

Type.-Male, No. 14224, U.S.N.M., Tehuacan, Mexico, September, 1910 (R. Müller).

\section{Genus ISCHNOPTERIX Hübner.}

ISCHNOPTERIX CONSTANTIA, new species.

Light gray with a russet tinge, irrorated with blackish; inner line black, single, erect from inner margin to subcostal, then bent at a rounded right angle to costa toward base; outer line oblique from costa, then roundedly bent at less than a right angle to inner margin, arcuate inward between veins 1 and 2 , with a point on vein 1 ; a black dash parallel to costa reaching outer margin below apex, diffused below and with whitish suffusion above before apex; a slight whitish suffusion near tornus; a fine terminal black line. Hind wing more uniformly russet-tinged, with a whitish dilution at apex; a mesial blackish line angled in the discal region and a little flexuous. Thorax dark, abdomen gray, collar dull ocher. Expanse, $47 \mathrm{~mm}$.

Type.-Female, No. 14225, U.S.N.M., Tehuacan, Mexico, September, 1910 (R. Müller).

\section{Genus OPISTHOXIA Hübner.}

\section{OPISTHOXIA CASSANDRA, new species.}

Russet purple, darker on the outer half of fore wing; a yellow bar on costa at basal third and a larger one beyond middle; a yellow line along inner margin, expanding triangularly opposite the outer costal spot; fringe russet at base, yellow outwardly. Hind wing with a subbasal yellow band that widens into a costal streak; an outer costal spot; termen and fringe yellow, the outline undulate; surface of the wing with transverse blackish strigæ and some leaden-colored scales before termen; a small black ocellus with yellow ring and metallic center subapically; some black accompanying the submarginal leaden 
spot below vein 6 . Beneath uniform silky whitish, the markings showing by transparency. Expanse, $24 \mathrm{~mm}$.

Type.-Female, No. 14226, U.S.N.M., Misantla, Mexico, April, 1911 (R. Müller).

This may be a variety of $O$. limboguttata Felder with the basal and terminal markings of fore wing confluent.

OPISTHOXIA SALUBEA, new species.

Russet purplish gray, the markings yellow, shaded with orange; costa diffusedly yellow from base, forming a large triangular mark subapically; a broad band from beyond middle of inner margin running upward to vein 4, rounded above and constricted centrally; margin orange shaded. Hind wing with the basal gray area sharply limited, the orange yellow disk beyond irrorated with purple and metallic scales; a small round ocellus subapically and still smaller one on margin below vein 6 ; area around upper ocellus somewhat clear of irrorations; fringe yellow. Expanse, $26 \mathrm{~mm}$.

Type.-Female, No. 14227, U.S.N.M., Misantla, Mexico, August, 1910 (R. Müller).

\section{Genus PHYLLODONTA Warren.}

\section{PHYLLODONTA EMERITA, new species.}

Gray or reddish; in one specimen the reddish color is confined to the basal space, in the other it covers the whole wing; inner line curved, wavy, olive brown, marked with glaucus, becoming blackish on inner margin; a short oblique brown line from costa mesially, ending beyond the small discal dot; outer line angled below costa, then straight, blackish, lined with glaucus, followed by small brown triangular marks; apex pointed; outer margin with a deep sinus below vein 3. Hind wing reddish gray or orange gray, with dark discal spot and mesial band; margin broadly gray, separated by a row of spots of the ground color from an outer gray band; margin with a sinus as on fore wing. Expanse, $44 \mathrm{~mm}$.

Cotypes.-Two females, No. 14296, U.S.N.M., Misantla, Mexico, June, 1910 (R. Müller); Jalapa, Mexico (Schaus collection).

\section{PHYLLODONTA PERIBLEPTARIA, new species.}

Wood-brown, finely irrorate with dark brown; lines brown, straight; inner line bent at right-angles subcostally; a minute discal dot; outer line oblique, without angulation, sending a long ray toward cell subcostally; an erect shade from tornus; outer margin projecting centrally, incised between the veins below. Hind wing with a line very near the base; mesial line straight, distinct; area beyond it slightly purplish shaded, darker at the anal angle; margin as on fore wing. Expanse, $38 \mathrm{~mm}$.

Type.-Female, No. 14297, U.S.N.M., Misantla, Mexico, July, 1910 (R. Müller). 


\section{Genus DIGONODES Warren.}

DIGONODES GNORIMARIA, new species.

Dark umber brown, the veins of fore wing lighter; inner line slightly curved, whitish, edged without with a black shading; discal mark a black ellipse, its center nearly occluded; outer line angled at vein 4, incurved above and below the angle, fine, white, with narrow black edging; outer margin irregular, with prominences at vein 4, vein 6 , and apex. Hind wing grayer brown, with round dark discal dot; outer mesial dark line with pale outer border, angled at vein 4 . Expanse, $49 \mathrm{~mm}$.

Type.-Female, No. 14243, U.S.N.M., Orizaba, Mexico, August, 1910 (R. Müller).

\section{DIGONODES AGONARIA, new species.}

Light wood-brown, but heavily mottled with blackish brown, the mottlings generally completely confluent in the outer part of the median space; inner line wavy, clouded, partly lost in the mottlings; a discal black ringlet; outer line projecting in the middle, wavy, edged without by a slightly paler line, which in dark specimens forms the outer edge of the shaded median space; margin pale but mottled with dark and with a dark subapical patch. Hind wing similar to fore wing, the markings less pronounced; discal dot black; outer line crenulate, preceded by dark shading; margin more clear of mottlings than the rest of the wing. The outer margins of both wings are entire, without angulations. Expanse, 39-41 mm.

Cotypes.-One male, six females, No. 14294, U.S.N.M., Cuernavaca, Mexico, June, 1906 (W. Schaus); Santa Rosa, State of Vera Cruz, Mexico, August, 1906 (W. Schaus); Zacualpan, Mexico, August, 1910 (R. Müller)

\section{Genus PARAGONIA Hübner.}

\section{PARAGONIA TISELAARIA, new species.}

Pale wood-brown; both wings densely mottled with dark red-brc wn from base to outer line, finely strigose beyond; inner line dark brown, bent subcostally, slightly flexuous; a small round discal dot; a semicircular purple-brown patch on costa before apex, from which the outer line is disconnected, but becomes distinct below; brown, slender, sending out lines along the veins, the spaces between filled with large olive patches; a submarginal row of olive patches, larger toward tornus. Hind wing with the mesial line followed by purplish and stained with olive; submarginal line olive, widening toward tornus; a slight angulation in the middle of each wing; antennae of male simple. Expanse, $37 \mathrm{~mm}$.

Type.-Male, No. 14295, U.S.N.M., Zacualpan, Mexico, January, 1911 (R. Müller). 


\section{Genus APICIA Guenée.}

\section{APICIA ISCHYRIZOARIA, new species.}

Fore wing with the apex pointed, the outer margin angled at vein 4 ; straw-color, more or less distinctly tinged with brown; lines nearly straight, approximating on inner margin, whitish, edged with brown within, the brown edging usually more obvious than the line itself; a rounded black discal dot; basal and terminal spaces dusted with purplish black irrorations, which form large clouded spots, one in center of basal space, three following outer line and one within the angle of the outer margin. These spots are sometimes confluent, sometimes faint. Hind wing with a single mesial line, followed by a central spot, which may be duplicated toward inner margin or have small patches toward apex and outer margin; discal dot present or absent. Expanse: Male, $31 \mathrm{~mm}$; female, $37 \mathrm{~mm}$.

Two males are dark rusty brown with the patches pale purplish and confluent. The females are both pale, with the patches pale purplish and confluent, but faint.

Cotypes.-Nine males, two females, No. 14244, U.S.N.M., Mexico City, Mexico, February, May, June, September, October, December, 1908, 1909, 1910 (R. Müller).

Mr. Schaus kindly examined both sexes of this species. The female he found to resemble Therina ascolia Druce, while the male might be easily mistaken for one of the forms of the female of Apicia distycharia Guenée. The species comes very close to Tetracis pagonaria Schaus, which is represented in the collection by females without any traces of the purplish patches. In the females of ischyrizoaria before me the purplish markings are much fainter than in the males, and it is possible that they may disappear.

\section{Genus THERINA Hübner.}

THERINA CALIDARIA, new species.

Wings semitranslucent pale brownish straw-color, densely irrorate with purple brown; lines purple brown, edged with dark ocher, narrow, slightly spotted on the veins, the outer line incurved a little below cell; a dark discal mark. Hind wing with a single outer mesial line like those on fore wing. Expanse, $35 \mathrm{~mm}$.

Cotypes.-Three females, No. 14245, U.S.N.M., Zacualpan, Mexico, August, 1909, 1910 (R. Müller).

\section{Genus TRYGODES Guenée.}

TRYGODES SIMPLICISSIMA, new species.

Wings translucent whitish, thickly irrorated with pale gray, the irrorations largely confluent; fore wing with two lines of gray, wavy, approximate, subparallel; hind wing with a single mesial line; 
a dark line on margin of both wings; outer margin angled at vein 4 on both wings. Expanse, $36 \mathrm{~mm}$.

Type.-Female, No. 14246, U.S.N.M., Orizaba, Mexico, November, 1907 (R. Müller).

\section{Genus METANEMA Guenée.}

METANEMA UGALLIA, new species.

Orange-ocherous, darker on the margin; lines of fore wing straight, parallel, oblique, purplish brown; a small discal dot; outer margin angled at vein 5 , the part above the angle slightly excavate. Hind wing with discal dot and faint reddish outer mesial line, the margin slightly angled. Expanse, $29 \mathrm{~mm}$.

Type--Male, No. 14247, U.S.N.M., Zacualpan, Mexico, August, 1909 (R. Müller).

\section{Genus ACANTHOPHORA Hulst.}

\section{ACANTHOPHORA MUELLERI, new species.}

White, speckled with black. Collar lined with black behind; abdomen spotted; tarsi broadly ringed. Fore wing with numerous strigose spots, which are clustered more densely in the regions of the usual transverse lines; a terminal row of spots. Hind wings lightly spotted, the spots grayish except along the margin. Beneath both wings are lightly spotted, the spots tending to form an outer mesial row. Expanse, $36 \mathrm{~mm}$.

Type.-Female, No. 14248, U.S.N.M., Mo'bano, Mexico, August, 1910 (R. Müller).

\section{Genus PIGIA Guenée.}

PIGIA CALOTIS, new species.

Ground color white with an ocherous tint about the lines; basal space powdered with brown; inner line single, brown, angled in cell, a little waved only below; median vein and venules brown-lined; discal cross-vein brown; median line straight, sharply angled at vein 6 , followed by a fainter parallel line, in the female by two such; these duplicate lines are finely dentate on the veins; outer line slender, brown, angled at vein 6 , incurved below, then outcurved and inward again at submedian fold; a brown line from apex touches the angle at vein 6 , most evident in the female; terminal space below this dash filled in with brown except for a series of lunate submarginal intravenular white patches; a fine brown terminal line. Hind wing similarly ornamented; two mesial lines, the second followed by a single line (in the male) or by two (in the female); outer line irregular, the terminal space filled with brown scaling except for the submarginal spots. Expanse, 18-19 mm.

Cotypes.-Two males, No. 14284, U.S.N.M., Iguala, State of Guerrero, Mexico, June, 1906 (W. Schaus); one female, Tehuacan, Mexico, September, 1909 (R. Müller). 


\section{HEMITHEINOPSIS, new genus.}

Fore wing with vein 3 from well before 4 ; 5 from middle of crossvein; 6 from end of cell; a long accessory cell formed from the anastomosis of 11 and 12 with the stalk of 7-8 and crossed by 9 which is weak; 7 from the accessory cell; $8-9$ stalked from its end; 10 from the accessory cell near its end; 11 from it also; 12 arising from base, but leaving the accessory cell before the anastomosis. Hind wing with vein 5 absent, 6 and 7 separate, 8 anastomosing with subcostal to beyond middle of cell. Legs slender; hind tibiæ with four spurs and a groove containing a hair-pencil. Antennæ of male bipectinate.

Genotype.-Hemitheinopsis pteroglauca, new species.

This genus falls in the Geometrinæ according to Prout $^{1}$ or the Fernaldellinæ according to Hulst, ${ }^{2}$ but does not seem ât all allied to the latter.

HEMITHEINOPSIS PTEROGLAUCA, new species.

Head and thorax tinged with green, abdomen whitish. Fore wing pale yellow-green, faintly mottled with white; two straight, parallel, white lines, oblique, the inner from inner third of inner margin to middle of costa, the outer from outer third of inner margin to costa close to apex. Hind wing white with a very faint greenish tinge. Expanse, $29 \mathrm{~mm}$.

Type.-Male, No. 14290, U.S.N.M., Zacualpan, Mexico, September, 1909 (R. Müller).

\section{HEMITHEINOPSIS PTEROCHRA, new species.}

Thorax tinged with ocher brown, darkest in front: abdomen white. Fore wing pale ocher brown, finely irrorated with darker; two parallel pale lines as in the preceding species, edged toward the center with darker brown, which is a little intensified on the veins. Hind wing creamy whitish, semitransparent. Expanse, $29 \mathrm{~mm}$.

Type.-Male, No. 14291, U.S.N.M., Zacualpan, Mexico, February, 1911 (R. Müller).

\section{Genus ANNEMORIA Packard.}

ANNEMORIA ORTHOGRAMMA, new species.

Fore wings green, finely irrorated with transverse white strigæ; two parallel broad white bands, the outer reaching the costa close to apex. Hind wing tinted with green except in an outer mesial line. Expanse, $29 \mathrm{~mm}$.

Cotypes.-Male and female, No. 14287, U.S.N.M., Mineras de Zacualpan, December, 1910, March, 1911 (R. Müller).

Similar to A. bistriaria Packard, but the white bands on fore wing are broader. 


\section{Genus BLECHROMA Möschler.}

BLECHROMA TISSTIGMARIA, new species.

Both wings green, marked with purple brown lines: Fore wing with the costa brown, especially beneath; an inner line strongly crenulate, tending to form points at the ends of the indentations; a large round discal mark surrounded by crenulations, being the upper segments of two lines that join above it; outer line similar to the inner, more strongly crenulate and largely obsolete except the dots at the ends of the indentations, appearing as two alternating rows of dots, the inner one nearest the costa larger and blurred. Hind wing with traces of both lines adjoining the inner margin and faint indications beyond; a row of small terminal dots on both wings. Expanse, $27 \mathrm{~mm}$.

Type.-Male, No. 14288, U.S.N.M., Misantla, Mexico, May, 1910 (R. Müller).

The specimen was examined by Mr. Schaus, who states that the species is in the British Museum without name.

\section{Genus RACHEOSPILA Guenée.}

\section{RACHEOSPILA MANOSTIGMA, new species.}

Vertex of head white, front purple; body green, the abdomen with large dorsal white spots edged with purple. Wings green; fore wing with the costa narrowly purple; three dots in a curved line representing the inner line; a round discal spot; seven dots representing the outer line, a little alternately waved. Hind wing with discal dot and traces of an outer row of dots. Both wings with a narrow red terminal line, the fringe white. Expanse, $25 \mathrm{~mm}$.

Type.-Female, No. 14289, U.S.N.M., Misantla, Mexico, May, 1910 (R. Müller).

Mr. Schaus examined the specimen and labeled it "Racheospila, sp., not in British Museum."

\section{CANOSYNTELES, nevv genus.}

Fore wing with vein 3 well before $4 ; 5$ from the middle of the crossvein; 6 from the end of the cell; 7-10 stalked, without accessory cell, 8 and 9 running to the costa well before apex (nearer the apex in the male than in the female); 11 from the cell; 12 free. Hind wing with vein 5 distinct, from the middle of the cross-vein; 6 and 7 stalked; 8 free from the cell but running very close to it in the middle. Antennæ of the male thickened and flattened; somewhat so also in the female. Vestiture long, hairy. Hind tibiæ with one pair of spurs. Eyes moderate. Palpi hardly exceeding the front.

Genotype.-Cænosynteles haploaria, new species. 
This genus falls in the Brephinæ, both by Hulst's and Prout's tables, where I feel obliged to leave it, though the appearance of the single species is quite unlike that of the other Brephinæ.

\section{CENOSYNTELES HAPLOARIA, new species.}

Gray; fore wing and thorax thickly gray-powdered on a whitish ground, which appears narrowly edging the lines outwardly from the median space; lines dark gray, densely but coarsely waved, the inner bent on median vein, the outer nearly straight; a small black discal dot near the outer line. Hind wing grayish, darker on the margin, with a dark mesial shaded line followed by whitish. Expanse, 32-40 mm. Abdomen with a dull ochraceous tint.

Cotypes.-Two males, four females, No. 14293, U.S.N.M., Tehuacan, Mexico, June, 1910; Zacualpan, Mexico, August, 1909 (R. Müller).

\section{Genus C@ENOCHARIS Hulst.}

\section{COENOCHARIS HOPLITARIA, new species.}

Whitish gray at base, along costa, in a subapical dash and discal mark, the rest of the wing carneous gray; basal space limited outwardly by a black line, dentate on vein 1 and in cell, obsoletely. traversing the whitish costal area; discal mark partly surrounded by black, angular, narrow in the male, broader in the female; an outer double blackish line, distinct only below, washed and shaded along the veins above; a dark terminal line in the female. Hind wing: fuscous stained, with a mesial dentate blackish slender line, followed by a dilution of the ground color. This mark not visible in the female. Beneath pale grayish, shining, immaculate. Expanse: Male, $29 \mathrm{~mm}$.; female, $33 \mathrm{~mm}$.

Cotypes.-Four males, one female, No. 14228, U.S.N.M., Tehuacan, Mexico, June, September, and October, 1910 (R. Müller).

\section{Genus ALCIS Curtis.}

\section{ALCIS CRETAFUNDA, new species.}

Chalky whitish, irrorated with black and ocherous brown; head and thorax dark; abdomen pale with dorsal spottings. Fore wing with the basal space solidly filled in with dark irrorations, leaving a narrow dilution before the inner line; a collection of irrorations in the center of costa; outer line slender, black, finely denticulate, incurved below vein 2 ; apex with several patches of black and brownish, leaving an irregular subapical mark of the ground color; subterminal line whitish, wavy, contrasted among the dark patches above, lost below; a row of terminal black dots between the veins. Hind wing similarly irrorated, with small dark discal dot and mesial denticulate submacular line, lost above; below it on inner margin a black dot followed by orange scales; terminal area grayish clouded, relieving a 
whitish line, irregularly undulate; black intervenular spots connected by a fine terminal black line. Expanse, $35 \mathrm{~mm}$.

Type.-Male, No. 14229 U.S.N.M., Misantla, Mexico, June, 1910 (R. Müller).

ALCIS ELPIDATA, new species.

Thorax dark, blackish gray; abdomen brown-gray. Fore wing blackish-shaded over a gray ground, which appears with a reddish tint in a quadrate area beyond cell and below middle of outer margin; lines lost in the general shading, the inner faintly traced, the outer excurved beyond the discal dilution; a black elliptical discal mark; discal veins black-lined; subterminal line whitish, wavy and flexuous. Hind wing with a straight dark shade across cell; a minute discal dot; an outer curved black line, followed by a fainter duplication; a submarginal dark irregularly wavy line preceded and followed by faint whitish macular shadings. Expanse, $30 \mathrm{~mm}$.

Type--Female, No. 14230, U.S.N.M., Tehuacan, Mexico, September, 1910 (R. Müller).

Possibly this is the female of the following species.

\section{ALCIS INTERBRUNNEA, new species.}

Thorax dark, blackish gray; abdomen brown-gray. Fore wing rather dark gray, reddish brown in lower third of median space, beyond cell and distinctly and broadly so on termen; lines black, rather broad, single; inner line excurved at cell, then retracted to basal fourth of inner margin; a faint mesial shade line with black inception on costa; an occluded black discal ringlet; outer line excurved over cell, strongly incurved below, cut by black dashes on veins 3 and 4 ; these dashes join the black subterminal line, which is far from margin and near the outer line; it is subparallel to the outer line but less strongly flexed and followed by a faint dilution before the brown terminal area. Hind wing with a straight dark shade across cell; a minute discal dot; an outer curved black line followed by a faint duplication; a submarginal dark irregularly wavy line followed by a faint dilution, the termen brown shaded. Expanse, $29 \mathrm{~mm}$.

Cotypes.-Thirty-four males, No. 14231, U.S.N.M., Tehuacan, Mexico, June, August, and September, 1910 (R. Müller).

\section{Family LASIOCAMPID五.}

\section{Genus CLAPHE Walker.}

CLAPHE NYSTAMMA, new species.

Fore wing light gray, overspread with brown; subbasal, inner and outer lines gray-black, doubled, shaded, the veins also partly blacklined; submarginal line a row of closely placed and rather large dots, with an inflexure opposite cell and submedian; a row of brown spots in the fringe. Hind wing dull yellowish, the basal half shaded 
with red; a blackish shaded mesial band, broad on costa, becoming obsolete below; a subterminal row of spots as on fore wing, becoming obsolete at anal angle. Thorax and base of abdomen blackish gray with some red intermixed; abdomen mostly dull reddish. Expanse, 33-34 mm.

Cotypes.-Males, No. 13954, U.S.N.M., Orizaba, Mexico, November, 1910 (R. Müller); Cordoba, Mexico, May, 1906 (W. Schaus).

Mr. Schaus compared the Cordoba specimen and marked it "Claphe boresa Schs. ? larger than the specimen in the British Museum." The species is allied to Claphe boresa, but differs in detail.

\section{Superfamily TINEOIDEA.}

Family NOLID王.

\section{Geuus RESELIA Hübner.}

\section{RESELIA PEDANTA, new species.}

Fore wing grayish white; inner line slender, brown, roundedly angled on median vein; a dark shade along costa, most distinct mesially; outer line oblique from costa over the discal venules, then bent and reentrant at vein 2 , then oblique and double to middle of inner margin; subterminal line black, shaded, oblique and waved from outer third of costa, incurved opposite median vein, then thickened and below paralleled to outer margin; irregular marginal brown stains except at apex. ${ }_{\star}$ Hind wing fuscous shaded, lighter on the disk. Expanse, $28 \mathrm{~mm}$.

Type.-Female, No. 14032, U.S.N.M., Misantla, Mexico, May, 1910 (R. Müller).

\section{Family COCHLIDIID $Æ$.}

\section{Genus EUCLEA Hübner.}

\section{EUCLEA POASICA, new species.}

Dark brown, broadly darker on termen and below cell; discal mark elongate, dark brown; a straight subapical silver dash at the edge of the dark termen; an elliptical patch of reddish raised scales above the middle of the inner margin. Hind wing lighter brown. Expanse, $27 \mathrm{~mm}$.

Type.-Male, No. 14078, U.S.N.M., Mount Poas, Costa Rica, May, 1909 (W. Schaus).

EUCLEA DISTRAHENS, new species.

Dark velvety brown, with darker streaks at base and within the two silvery streaks; discal dot round, dark brown; subapical silvery mark straight, followed by a lightening of the ground; subbasal silvery line straight, slightly outwardly oblique below, followed by an 
illy defined light reddish patch; veins outwardly lined in dark. Hind wing lighter brown. Expanse, $27 \mathrm{~mm}$.

Type.-Male, No. 14079, U.S.N.M., Sixola River, Costa Rica, December 3, 1909 (W. Schaus).

\section{EUCLEA BUSCKI, new species.}

Thorax dark red-brown; abdomen blackish brown. Fore wing blackish brown with a thin semihyaline aspect between all the veins over the disk; apex red brown, as also the extreme tip of outer margin; a fine red-brown line the length of vein 1 ; a faint pale line parallel to the outer margin, within which on the discal venules is a small pale area; discal dot black, elongate; subapical silvery mark composed of two or three dots; subbasal silvery mark a slender line, oblique in its general course and strongly looped inward in its middle third. Hind wing blackish brown, reddish shaded on the costa. Expanse, $21 \mathrm{~mm}$.

Type.-Male, No. 14285, U.S.N.M., Cabima, Panama, May, 1911 (A. Busck).

I have named this species in honor of Mr. August Busck, the collector.

\section{Genus METRAGA Walker.}

METRAGA COLLE, new species.

Blackish brown, lighter over the disk, relieving the round blackish discal spot; subbasal line violaceous silvery, preceded and followed by velvety black; subapical line also violaceous silvery but slender and indistinct; a curved dark line connecting them. Hind wing chocolate brown. Expanse, $21 \mathrm{~mm}$.

Type.-Male, No. 14080, U.S.N.M., Carillo, Costa Rica, October 1908 (W. Schaus).

\section{METRAGA BYRNE, new species.}

Sandy yellowish brown; a narrow pale line nearly parallel to outer margin at outer third of wing, indistinct except centrally; fringes pale. Hind wing uniform brown. Expanse, $17 \mathrm{~mm}$.

Type.-Male, No. 14081, U.S.N.M., Sixola River, Costa Rica, March, 1909 (W. Schaus).

Genus SEMYRA Walker.

SEMYRA EUCHARISTA, new species.

Reddish brown; subbasal silvery line at inner fourth of wing, showing two angles, the points and ends of the line slightly enlarged, making four spots united by a zigzag line; a red patch in the uppermost angle; outer line defined by black within, oblique outwardly on costa, angled inward on median, followed by a purplish shade that makes digitate projections on the middle third of the wing; subter- 
minal line curved at apex, silvery, cutting off a dark brown patch at apex, then obliquely toward inner margin, but lost below; an angular velvety brown patch between this and the digitate projections near middle of wing. Hind wing red-brown. Expanse, $25 \mathrm{~mm}$.

Type.-Female, No. 14082, U.S.N.M., "unf. Brésil." (collector unknown).

NAROSOPSIS, new genus.

Antennæ of the male bipectinated at the base, the terminal third coarsely serrate; palpi upturned to the middle of the front, thick, the end joint short; veins 2 and 3 of fore wing well separated; spurs of the mid tibiæ long and distinct; vein 7 of fore wing from the cell; thorax with posterior truncated tuft.

Genotype.-Narosopsis leucospila, new species.

NAROSOPSIS LEUCOSPILA, new species.

White; fore wing outwardly shaded with purplish brown in which are scattered blackish scales forming a line from costa before apex toward tornus. Hind wing grayish shaded, especially on the veins. Expanse, $17 \mathrm{~mm}$.

Type.-Male, No. 14083, U.S.N.M., Sixola River, Costa Rica, September, 1909 (W. Schaus).

\section{Genus EUPROSTERNA Dyar.}

EQUPROSTERNA HOSIA, new species.

Bronzy brown, the apex purplish brown, shaded; two indistinct parallel dark lines across the wing. Hind wing dark chocolate brown. Expanse, $17 \mathrm{~mm}$.

Type.-Male, No. 14084, U.S.N.M., Carillo, Costa Rica, August 2, 1909 (W. Schaus).

\section{Genus NATADA Walker.}

NATADA MrCHORTA, new species.

Head and collar shaded with orange; else carneous brown; fore wing lustrous silky brown with transverse impressed lines, somewhat irrorate with dark scales, the base and anal angle with a slight orange tint, the apex purplish; outer margin shallowly emarginate on upper half. Hind wing uniform brown. Expanse, $25 \mathrm{~mm}$.

Type.-Male, No. 14085, U.S.N.M., Esparta, Costa Rica, May 25, 1908 (W. Schaus).

NATADA NINDLA, new species.

Head and collar broadly yellow, the color invading the center of the thorax; rest of thorax dark purplish brown; fore wing of the same dark brown; a blackish patch at lower angle of cell and one 
on inner margin below it; region around these marks somewhat darker shaded; a dark line from outer fourth of costa curves outward to outer margin above tornus with a branch obliquely inward to inner margin beyond middle. Hind wings and abdomen light silky brown. Expanse, $28 \mathrm{~mm}$.

Type.-Male, No. 14086, U.S.N.M., Sixola River, Costa Rica, March, 1909 (W. Schaus).

\section{Genus EPIPEROLA Dyar.}

EPIPEROLA CONFORMIS, new species.

Dark purplish brown; a pale oblique line from costa before apex to middle of inner margin; beyond it the ground color is lighter than within. Hind wing brown, lighter at the base. Expanse, $24 \mathrm{~mm}$.

Type.-Male, No. 14087, U.S.N.M., Colima, Mexico (J. Doll).

EPIPEROLA PAIDA, new species.

Ocherous whitish; thorax intermixed with brown and blackishtipped scales. Fore wing densely irrorated with brown, nearly obscuring the ground color, which shows most along the margin and in lined at the base; a rounded dark discal dot; a mesial curved line, slender, pale, parallel to the outer margin though remote from it, slightly defined by darker inwardly and followed by a broad brown shade; fringe dark, but lighter at the anal angle. Hind wing of the pale ground color, with a small dark patch at the anal angle. Expanse, $16 \mathrm{~mm}$.

Type.-Male, No. 14286, U.S.N.M., Trinidad River, Panama, May. 1911 (A. Busck).

\section{Genus PEROLA Walker.}

PEROLA PRODUCTA, new species.

Fore wing long, produced, the outer margin strongly oblique, the inner margin short; yellowish ocher, the costa broadly shaded with red-brown; two parallel bands of this color from either side of apex to inner margin near base, the submarginal band fainter than the mesial one. Hind wing shaded with red-brown; body parts darker than the wings. Expanse, $40 \mathrm{~mm}$.

Type--Male, No. 14088, U.S.N.M., Tuis, Costa Rica, June (W. Schaus).

\section{PEROLA BREVICORNIS, new species.}

Antennæ very short; fore wing trigonate; ground whitish strawcolor, the costal third broadly shaded with dark brown; inner half of inner area shaded with ocherous, leaving the pale ground in a triangle resting on outer margin; cell marked with darker streaks, one such 
beyond it; a dark line from apex curves inward to vein 6 , then downward curving across the light field into the ocherous area where it ends parallel to inner margin, crenulate, followed by a lighter area; from vein 6 a branch runs out nearly to margin, then is continued as a row of submarginal dots toward tornus. Hind wing whitish strawcolor, dusted with brown, especially on inner margin; veins darker. Expanse, $38 \mathrm{~mm}$.

Type.-Male, No. 14089, U.S.N.M., Tuis, Costa Rica, June, 1909 (W. Schaus).

MICROPHOBETRON, new genus.

Antennæ long, thickened and flattened, simple; hind tibiæ with four long spurs; palpi upturned, not reaching vertex; form slender, abdomen short, tapering; head small but prominent; fore wing with veins 8-9 stalked, all the rest from the cell.

Genotype.-Microphobetron rebella, new species.

MICROPHOBETRON REBELLA, new species.

Bronzy brownish black, the hind wings a little lighter than the fore wings. Expanse, $11.5 \mathrm{~mm}$.

Type.-Male, No. 14090, U.S.N.M., Sixola River, Costa Rica, March, 1909 (W. Schaus).

\section{Genus VIPSOPHOBETRON Dyar.}

\section{VIPSOPHOBETRON DENDERIA, new species.}

Collar ocherous brown; thorax dark brown; fore wing very dark brown at the base, sharply limited outwardly from middle of costa to tornus, the edge of the dark area incurved centrally; on inner margin a semilunate area of leaden brown with black flecks in its upper edge; apex ocher-brown with a small dark spot before the tip. Hind wing and abdomen brown. Expanse, $24 \mathrm{~mm}$.

Type--Male, No. 14091, U.S.N.M., Sixola River, Costa Rica, March 14, 1909 (W. Schaus).

\section{Genus PSEUDOVIPSANIA Dyar.}

\section{PSEUDOVIPSANIA MELANOIS, new species.}

Collar and disk of thorax pinkish and gray; thorax and base of abdomen leaden gray; abdomen black, the anal tuft orange; fore wing long, produced, leaden black, the discal area subhyaline, in which the veins bordering the cell are thickened with black scales. Hind wing similar, the translucent area extending to the margin; hind wing small, produced-trigonate. Expanse, $28 \mathrm{~mm}$.

Type.-Male, No. 14092, U.S.N.M., Tuis, Costa Rica, August, 1909 (W. Schaus). 


\section{Genus DICHROMAPTERYX Dyar.}

DICHROMAPTERYX DIDYMA, new species.

Dark lustrous brown; fore wing with a pale leaden line from middle of costa to tornus, beyond which the color is of a more lilaceous tint but not much lighter. Hind wing dark brown. Expanse, $21 \mathrm{~mm}$.

Type--Male, No. 14093, U.S.N.M., Carillo, Costa Rica, October, 1909 (W. Schaus).

Similar to Dichromapteryx obscura Dyar, but the serrations of the antennæ are longer.

Family ZYGÆNIDA.

Genus GINGLA Walker.

GINGLA MYRLA, new species.

Entirely black, with a blue-green reflection. The wings are broad and squarely rounded, thinly scaled, semitranslucent. Expanse, $19 \mathrm{~mm}$.

Type.-No. 13862, U.S.N.M., Mexico City, Mexico, Julv, 1910 (R. Müller).

GINGLA ASTORA, new species.

Fore wing black, but with a brown tint from the color of the under side; an ocher yellow ray just below costal edge from base to beyond middle; margin black. Hind wing bright ocher yellow, the margin narrowly black. Beneath both wings ocher yellow with black fringes. Body parts entirely black. Expanse, $13 \mathrm{~mm}$.

Type.-No. 13863, U.S.N.M., Popocatepetl Park, Mexico, 8,00010,000 feet, July, 1906 (W. Schaus).

\section{Genus ADSCITA Retzius.}

\section{ADSCITA MORELIA, new species.}

Black with strong green reflection. Fore wing uniformly of this color. Hind wing hyaline in the middle, the veins and margins black, the black dull, without green luster above, but strongly green below, except on the hyaline part. Tongue reddish brown, contrasted in color between the small black palpi. Expanse, $25 \mathrm{~mm}$.

Type.-No. 13864, U.S.N.M., Morelos, Mexico, 7,000 feet (W. Schaus).

\section{Genus HARRISINA Packard.}

HARRISINA AUCHENOCHRYSA, new species.

Black with moderate bluish reflection. Head, except the front, collar, and anterior half of thorax orange color. Expanse, $24 \mathrm{~mm}$.

Type--No. 13865, U.S.N.M., Cordoba, Mexico, May 17, 1908 (F. Knab.) 
HARRISINA TESSACANS, new species.

Fore wing blue-black; hind wing duller black, but with some blue luster. Beneath with blue luster. Collar broadly orange-yellow. Expanse, $28 \mathrm{~mm}$.

Type.-Male, No. 14219, U.S.N.M., Tehuacan, Mexico, April, 1911 (R. Müller).

\section{Genus ACOLOITHUS Clemens.}

\section{ACOLOITHUS ERYTHROZONA, new species.}

Black, the wings not very densely scaled and with very little metallic reflection; what is present is bluish. Abdomen crimson except the basal and terminal segments. Expanse, $20 \mathrm{~mm}$.

Type.-No. 13866, U.S.N.M., Mexico City, Mexico, August, 1910 (R. Müller).

\section{Genus PSEUDOTALARA Druce.}

\section{PSEUDOTALARA PSEUDOPHILE, new species.}

Wings dark leaden gray, the hind wings a little less metallic than the fore wings; an orange band on collar running around the head and staining its posterior portion. Expanse, $17 \mathrm{~mm}$.

Type.-No. 13867, U.S.N.M., Oaxaca, Mexico (Schaus collection).

PSEUDOTALARA LATERALIS, new species.

Bright orange color. Costal edge of fore wing and outer margin narrowly black. Hind wing with a black border on margin, broadest at apex. Head black on vortex with a few orange scales in front; disk of thorax orange; legs black; abdomen orange on the sides, black dorsally and ventrally. Expanse, $26 \mathrm{~mm}$.

Type.-No. 13868, U.S.N.M., Misantla, Mexico, November, 1910 (R. Müller).

\section{Family CASTNIID无.}

\section{Genus CASTNIA Fabricius.}

\section{CASTNIA THYSANETE, new species.}

Black; fore wing washed with whitish beyond cell and in lower part of subterminal space, the white irrorated with black and assuming a leaden tint on inner margin; a white oblique bar on costa at end of cell; two white subapical spots; outer line oblique, straight, from middle of inner margin to costa before apex, black, defined whitish within, lost apically in the region of the white spots; the line is followed by black lunules of the ground color above vein $1 \mathrm{c}$, running into the black termen above. Hind wing with a red mesial bar and two outer rows of creamy white spots, the inner row small and dif- 
fused, the outer row large and parallel to the margin, but with diffused edges. Expanse, $79 \mathrm{~mm}$.

Type.-Female, No. 14031, U.S.N.M., Tehuacan, Mexico, June, 1910 (R. Müller).

Mr. Schaus has compared the specimen in London

Family PYRALIDÆ.

Subfamily PYRAUSTIN AE.

Genus OMPHISA Moore.

OMPHISA BRUNNETTALIS, new species.

Reddish brown; fore wing with white semihyaline spaces as follows: A square spot at end on cell and small spot near its base; an outer row of squarish spots in two rows, separated by a slender line of the ground color, the inner spots partly confluent, the outer ones smaller and separate; the row is incurved below so that the spots at base of vein 2 touch the cell. Hind wing whitish; an ocher discal spot edged with brown; a double waved outer blackish line, the two lines of which it is composed touching on the veins so as to define spots of the ground color; termen beyond this line light brown. Expanse, $40-50 \mathrm{~mm}$.

Cotypes.-Four males, one female, No. 14033, U.S.N.M., Zacualpan, Mexico, August, 1909 (R. Müller).

\section{Genus POLYGRAMMODES Guenée.}

\section{POLYGRAMMODES HIRTALOIDALIS, new species.}

Wings pale yellow; fore wing with a brown patch at the base, running broadly along inner margin nearly to tornus; inner line outwardly oblique, running into the brown shade below orbicular; orbicular yellow in a black ring; reniform quadrate, brown, edged with black; outer line brown, slender, waved, touching the brown shade at vein 2 , then reentrant and forming a loop touching the reniform beneath; a black subapical patch below subcostal vein, excavate on its outer side and somewhat dentate within. Hind wing with a discal ringlet and a black bar from thence to inner margin, where it is surrounded by a brown cloud; a wavy mesial line, distinct only on its costal segment; a submarginal line, blotched costally, elsewhere faint. Expanse, $34 \mathrm{~mm}$.

Type--Female, No. 14034, U.S.N.M., Mexico City, Mexico, September, 1910.

POLYGRAMMODES MODESTALIS, new species.

Light brown, the abdomen with a double row of dorsal white spots. Fore wing with the veins and lines dark brown; cell a little lighter as also the interspaces between the outer and subterminal lines; 
costa and fringe dark brown; inner line arcuate, dentate a little on the veins, far from base; outer line oblique, similar to the other; reniform and orbicular round, brown, fused to the edges of the cell; subterminal line dentate, connected with the outer line by a line between veins 2 and 5; a terminal row of pale yellowish marks. Hind wing whitish, tinged with brown, the veins brown; discal mark large, brown; median line straight, dentate; submarginal line somewhat dislocated on the veins, joined to the mesial line between veins 2 and 5 as on fore wing; terminal space red-brown; fringe dark, with basal and central darker lines. Expanse, $44 \mathrm{~mm}$.

Type.-Female, No. 14035, U.S.N.M., Orizaba, Mexico, June, 1910 (R. Müller)

\section{Genus PHRYGANODES Guenée.}

\section{PHRYGANODES LEUCOPHASMA, new species.}

Tan-brown, with white subhyaline spaces; a speck near base of cell and larger one below; a round spot in end of cell; a pyriform one below it from which extend in the usual incurved course of the subterminal line five spots to costa, the three below small and dislocated by a blackish cloud, the two upper larger, quadrate and fused; all the spots more or less continuously edged with black; fringe blackishshaded with a whitish spot at tornus. Hind wing with two spots touching at their angles, the one on inner margin running into the cell, the discal one farther out and running upward toward costa; fringe streaked with blackish; apex a little shaded with blackish. Expanse, $30 \mathrm{~mm}$.

Cotypes.-Males, No. 14036, U.S.N.M., Sierra de Guerrero, Mexico, October, November, and December, 1910 (R. Müller).

\section{PHRYGANODES ANCHORITALIS, new species.}

Umber brown, the median space of fore wing lighter, more yellowish brown; lines broad, brown-black, the inner curved, the outer scarcely irregular; a small orbicular of brown; reniform a bar. Hind wing with mesial line and discal dot not much darker than the ground color. Beneath the wings are lighter and more grayish; discal dots black on both wings, small; outer line dark, shaded, indistinct. Expanse, $24 \mathrm{~mm}$.

Type.-Female, No. 14037, U.S.N.M., Misantla, Mexico, August, 1910 (R. Müller).

\section{PHRYGANODOS MOSTELLA, new species.}

Smooth gray with an olivaceous tint; lines blackish, the inner bent down on its lower third; a lunate discal mark; outer line squarely projected outward in its middle third, the lower segment thickened and followed indistinctly by whitish. Hind wing with 
whitish along costa, else colored as the fore wing; mesial line projected in the middle, the projected segment somewhat more distinctly broken into dots than on the fore wing. Costa at base in the male with a bladder-like swelling and a tuft of whitish hairs below. Expanse, $34 \mathrm{~mm}$.

Type--Male, No. 14038, U.S.N.M., Orizaba, Mexico, January, 1909 (R. Müller).

Mr. Schaus remarked upon this specimen that it is like $P$. omphatobasis Hampson, but with the lines more distinct.

\section{Genus PILOCROCIS Lederer.}

PILOCROCIS CAUDATELLA, new species.

Straw-color, shaded with brown except the median space on fore wing and base of hind wing; inner line blackish, curved; orbicular a dot; reniform an oval ringlet; outer line with its middle segment projected, with three rounded teeth, the lower segment oblique; a black cloud near middle of termen; a line at base of fringe. Hind wing with discal dot and mesial line similar to the outer line of fore wing; a line at base of fringe. Antennæ of the male with a tuft of black hair in the middle; abdomen with a terminal brush of light brown hairs; a black spot on fore tibia; a black dorsal line on second abdominal segment; a curved line on penultimate segment with double dorsal lines on the last. Expanse, $25 \mathrm{~mm}$.

Type.-Male, No. 14039, U.S.N.M., Misantla, Mexico, June, 1910 (R. Müller).

Mr. Schaus kindly examined the specimen.

\section{Genus PYRAUSTA Shrank. \\ PYRAUSTA DILECTICOLOR, new species.}

Yellow and bronzy brown; fore wing with a central yellow mark composed of two elliptical spots, the inner nearly crossing the wing, the outer from vein 2 to costa, joined by a dash on median vein; slight indistinct spots in a line beyond the outer edge of each. Hind wing with the base yellow, limited by a mesial line with its middle segment projected and defined from the outer ground by a parallel row of yellow dots; a brown discal patch. Fringe indistinctly spotted with yellow on both wings. Termen of hind wing excavated at anal ange. Expanse, $22 \mathrm{~mm}$.

Type.-Female, No. 14040, U.S.N.M., Misantla, Mexico, October, 1909 (R. Müller).

\section{Genus DICHOGAMA Lederer.}

DICHOGAMA COLOTHA, new species.

White; costa of fore wing narrowly black to the outer line; inner line straight, black, oblique from costa at base to inner third of inner 
margin; mesial line parallel to it, from inner fourth of costa to middle of inner margin; an oblique parallel bar from costa at end of cell, sending out black streaks along veins 2 to 6 in a gray shade; outer line from costa at outer fourth, excurved nearly to termen, incurved to inner margin at mesial line; a vermillion red half band on termen from apex to vein 2, followed below by a curved gray shade; a row of terminal black dots in the red; fringe leaden gray. Hind wing white, semihyaline, with a dark gray terminal shade on upper half. Expanse, $28 \mathrm{~mm}$.

Type.-Female, No. 14292, U.S.N.M., Tehuacan, Mexico, June, 1911 (R. Müller).

Genus LYGROPIA Lederer.

LYGROPIA SUBCOSTALIS, new species.

Dark brownish yellow, the wings shining, the hind pair a little paler; a black line along the costa of fore wings beneath; legs with the tibiæ and tarsi black; antennæ black with the tips white; third joint of palpi black. Expanse, $18 \mathrm{~mm}$.

Type.-Male, No. 14208, U.S.N.M., Orizaba, Mexico, May, 1911 (R. Müller).

\section{Genus CLINIODES Guenée.}

CLINIODES NOMADALIS, new species.

Shining pale yellow; costa brown on basal two-thirds with expansion at middle and end of cell; a gray-brown shade along inner and outer margins, narrowing to apex; inner line curved, distinct only at the costal expansion; an erect blackish bar at middle of inner margin; outer line curved, finely crenulate, expanded and brown on costa, also expanded but black on inner margin. Hind wing translucent opalescent whitish. Expanse, $33 \mathrm{~mm}$.

Type.-Male, No. 14041, U.S.N.M., Misantla, Mexico, April, 1911 (R. Müller).

\section{Subfamily CRAMBIN AE. \\ Genus CHILO Zincken.}

CHILO DILETANTELLUS, new species.

Straw yellow; fore wing with a dark-brown ray from base through the cell to termen, broadest in the middle; a silvery white shade below it; inner margin coarsely dusted with brown; fringe shining. Hind wing soiled whitish with pale gray apex. Expanse, $43 \mathrm{~mm}$.

Type.-Female, No. 14042, U.S.N.M., Cuernavaca, Mexico, June, 1906 (W. Schaus). 


\section{CHILO DUOMITA, new species.}

Straw yellow; fore wing shaded and dusted with brown except for an area on inner margin, which is terminated irregularly above by a faint brown line from base, that is curved down nearly to margin at basal third, then up to end of cell, and finally runs across the brown part to apex; a dark discal point; fringe dark. Hind wing whitish, silky, a little soiled along the veins. Expanse, $50 \mathrm{~mm}$.

Type.-Female, No. 14043, U.S.N.M., Coatepec, Mexico, October, 1910 (R. Müller).

\section{Subfamily PHYCITIN AE.}

\section{Genus SEMATONEURA Ragonot.}

SEMATONEURA DENTICOSELLA, new species.

Fore wing gray on costal third, the rest red-brown; the colors not sharply defined but mingled on the middle of the wing in streaks and dashes; some blackish streaks, which in the position of the outer line are edged with gray, forming long digitate dentations. Hind wing translucent, opalescent, becoming gray at apex and fringe. Expanse, $40 \mathrm{~mm}$.

Cotypes.-Females, No. 14044, U.S.N.M., Orizaba, Mexico, October, 1908; Misantla, Mexico, August, 1910 (R. Müller).

\section{Genus ANCYLOSTOMIA Ragonot.}

\section{ANCYLOSTOMIA ROSEITINCTELLA, new species.}

Straw yellow; a deep rosy shade mixed with gray from inner third of costa to apex, broadest in the middle; a similar shade on inner margin from near base to termen, widening outwardly; these two leave a broad ray of the yellow ground between them in which rests the round discal dot. Hind wing translucent, opalescent, gray at apex and outer margin, but the fringe silky white. Expanse, $31 \mathrm{~mm}$.

Cotypes.-Females, No. 14045, U.S.N.M., Cuernavaca, Mexico, July, 1906 (W. Schaus); July, 1909 (R. Müller).

\section{Family COSSID Æ.}

\section{Genus ACOSSUS Dyar. \\ ACOSSUS LEUCEGCHYTUS, new species.}

Gray, the basal half of fore wing shaded with black, the outer half with white shadings, most distinct in a large reniform area and above tornus; reticulations fine, black, with larger coarse heavy ones beyond the middle, forming a large $\mathrm{X}$-mark on the disk, its outer limbs forked toward apex and tornus respectively. Hind wing grayish, reticulated beneath, which shows by transparency. Thorax and abdomen dark and shaded with blackish. Expanse, $47 \mathrm{~mm}$.

Type.-Male, No. 14209, U.S.N.M., Mina San Rafael, San Luis Potosi, Mexico, May, 1911 (R. Müller). 
Genus GIVIRA Walker.

GIVIRA SANDELPHON, new species.

Body dark silky gray without markings. Base of fore wing blackish gray, quadrately reticulated with paler; middle third of wing lighter gray, the cell filled with pale luteous; following this across middle of wing a blackish gray slightly oblique band, very slightly reticulated; terminal third of wing lilacine gray, inclosing an outer narrow, broken, and somewhat reticulated line; across the apex a black band, with reticulated projections and a whitish inner bordering dilution; a small dark mark with reticular projection on tornus. Hind wing blackish gray, with a few strigæ and traces of reticulations, showing especially as markings on the termen. Beneath much lighter, the dark markings of fore wing repeated, the hind wing pale gray with the broken reticulations and strigæ more distinct. Fxpanse, $34 \mathrm{~mm}$.

Type.-Male, No. 14236, U.S.N.M., Misantla, Mexico, March, 1911 (R. Müller). 


\section{$2 \mathrm{BHL}$ Biodiversity Heritage Library}

Dyar, Harrison G. 1912. "Descriptions of new species and genera of Lepidoptera, chiefly from Mexico." Proceedings of the United States National Museum 42(1885), 39-106. https://doi.org/10.5479/si.00963801.42-1885.39.

View This Item Online: $\underline{\text { https://www.biodiversitylibrary.org/item/32500 }}$

DOI: https://doi.org/10.5479/si.00963801.42-1885.39

Permalink: https://www.biodiversitylibrary.org/partpdf/13650

\section{Holding Institution}

Smithsonian Libraries

\section{Sponsored by}

Smithsonian

\section{Copyright \& Reuse}

Copyright Status: NOT_IN_COPYRIGHT

This document was created from content at the Biodiversity Heritage Library, the world's largest open access digital library for biodiversity literature and archives. Visit BHL at https://www.biodiversitylibrary.org. 